\title{
"Cultural TOURISM" IN BALI: Cultural Performances as TOURIST ATTRACTION*
}

\author{
Michel Picard
}

\author{
"In the temple we ask for a blessing, \\ and at a hotel we ask for money" \\ "It's a ritual dance to ask the gods \\ for a lot of tourists"
}

Culture is Bali's defining feature, and Balinese culture is renowned for its dynamic resilience. The Balinese have been readily praised for their ability to borrow whatever foreign influence suits them while nevertheless maintaining their identity over the centuries. Today, there is no dearth of observers to claim that the Balinese have adjusted to the tourist invasion of their island just as in the past-taking advantage of the appeal of their cultural traditions to foreign visitors without sacrificing their own values on the altar of monetary profit. The following quotation should suffice as an example of such an established conviction:

The Balinese seem to be coping with the tourist invasion as well as they have coped with others, that is they are taking what they want, but they are not allowing them-

\footnotetext{
*This article is a revised version of a paper given at the International Workshop on Indonesian Studies, Balinese State and Society: Historical, Textual and Anthropological Approaches, held at the Royal Institute of Linguistics and Anthropology (KITLV), Leiden, April 21-24, 1986. It is based on research undertaken in Bali during 1981 and 1982. The field work was accomplished under the auspices of the Lembaga Ilmu Pengetahuan Indonesia and benefited from the institutional patronage of Prof. Dr. I Gusti Ngurah Bagus, Head of the Department of Anthropology at the Universitas Udayana. Besides Professor Bagus, I would like to thank my colleagues in the Unité de Recherche en Sociologie du Tourisme International of the Centre National de la Recherche Scientifique-Marie-Francoise Lanfant, Claude Bazin, and Jacques de Weerdt-for helping me elaborate the theoretical framework which structured my field work. I would also like to thank Edward Bruner, Hildred Geertz, and Jean-François Guermonprez for their comments, as well as Deborah Dunn and Kunang Helmi for their assistance in conveying my thoughts in English. My research resulted in a PhD dissertation entitled "Tourisme culturel' et 'culture touristique.' Rite et divertissement dans les arts du spectacle à Bali"
} 
selves to be any the less Balinese. This appears to have been the story throughout Bali's history, outside cultures have come, perhaps as conquerors, perhaps only as visitors and traders, but Balinese society and culture have remained distinctive, accepting outward forms, but molding them to its own different purposes." 1

Conclusions drawn in the early 1970 s by the American anthropologist Philip McKean from his study of the impact of tourism on Balinese culture support this argument. Challenging the charge of corruption commonly laid against tourism by foreign intellectuals, McKean, for his part, is interested in the capacity of the Balinese to reap the fruits of tourism and turn them to their advantage. In his eyes, the coming of tourists to their island indeed provides the Balinese with an opportunity to preserve their social fabric while revitalizing their cultural traditions:

In short, and perhaps most dramatically stated, the traditions of Bali will prosper in direct proportion to the success of the tourist industry. Far from destroying, ruining, or "spoiling" the culture of Bali, I am arguing here that the advent and increase of tourists is likely to fortify and foster the arts: dance, music, architecture, carving and painting. ${ }^{2}$

To support his point, McKean makes use of the conception of culture as "performance" propounded by Milton Singer. He sees the various manifestations of Balinese culture as "cultural performances," which distinguish between various audiences-namely the gods, the Balinese, and the tourists. In his opinion, the belief that a divine audience is present at performances intended for the Balinese acts as a guarantee for the preservation of traditional values, whereas performances designed for visitors have but a commercial purpose and thus lack religious meaning. In this respect the presence of tourists, far from diminishing the importance or quality of performances intended for divine and Balinese audiences, helps to improve their presentation, through the monetary rewards brought in by commercial shows. Thus traditional performances provide a sense of authenticity to the tourist shows, whereas the tourist performances contribute toward the traditional ones.

If Balinese performances have indeed improved, it is because the presence of tourists in their midst did not induce the Balinese to substitute new roles for the existing ones, but on the contrary drove them to add original roles to their traditional repertoire. Thus, according to McKean, tourism has reinforced a sense of boundary maintenance among the Balinese between what they do for themselves and what they do for their visitors:

Acknowledging that there is "leakage" across the boundaries between the realms, I nevertheless have argued that for a number of social, religious, and economic reasons, the Balinese are likely to keep the realms distinct in terms of content, though inter-related in terms of structure. ${ }^{3}$

(Paris: Ecole des Hautes Etudes en Sciences Sociales, 1984).

${ }^{1}$ A. Forge, "Bali" (manuscript, 1977), pp. 5-6. For similar opinion see also F. B. Eiseman Jr., Bali. Sekala and Niskala, Vol.1 (Denpasar: 1985), pp. 113-14; W. D. McTaggart, "Tourism and Tradition in Bali," World Development 8 (1980): 463-64; U. Ramseyer, The Art and Culture of Bali (London: Oxford University Press, 1977), p. 239.

2P. F. McKean, "Cultural Involution: Tourists, Balinese, and the Process of Modernization in an Anthropological Perspective" (PhD dissertation, Brown University, 1973), p. 1.

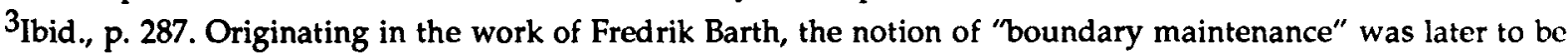
taken up in numerous studies dealing with the impact of tourism on indigenous cultures. In these studies, the capacity of a local population to maintain a duality of meanings - that is, a cultural performance will continue 
McKean's thesis was destined to have significant repercussions, in Bali as well as abroad. Within the context of the academic literature on the so-called "social and cultural impact of tourism," it greatly contributed toward promoting this island as an enviable model of a tourist policy that respected the cultural values of its population. 4 But even more important seems the fact that the conclusion of his study appeared just in the nick of time to comfort the position the Balinese authorities had adopted with respect to tourism.

\section{The Development of Tourism in Bali}

Before discussing this, some information about the circumstances surrounding the development of tourism in Bali is required.

Begun in 1846, the Dutch conquest of Bali ended in 1906-1908, with the fight to the death (puputan) of the Rajas of Bandung and Klungkung, who, with their respective families and followers, chose a glorious end rather than capitulate to the foreign invaders. ${ }^{5}$ The protests raised by this brutality were a source of international embarrassment to the Dutch, who attempted to atone for the bloodbath by presenting a positive image of their colonial policy on the island. The situation has aptly been summed up by Adrian Vickers:

The scar on the liberal imagination of the Netherlands produced by these massacres had to be healed, and preservation of Balinese culture, in combination with tourism, were the most effective balms for the healing process. ${ }^{6}$

Here, the so-called "Ethical Policy" was combined with the vision of Balinese culture held by the Orientalist tradition. Since the days of Raffles, Bali had been seen as a "living museum" of Majapahit Java, and the enlightened colonial policy designed for the island aimed to preserve Balinese culture, and even return it to its former state. ${ }^{7}$ Once restored to its pristine splendour, Balinese culture could then be presented for the appreciation of the outside world.

It was in 1908, the very year which saw the fall of Bali's last Raja, that tourism in the

to have significance for the native people independent of the presence of tourists, and it would take place even in the absence of a foreign audience-has been selected as a criterion permitting their authors to evaluate the integrity of the culture under scrutiny. Restricting ouselves to the case of Bali, Raymond Noronha and Jean-Luc Maurer adopted McKean's argument, without seeking to assess its validity. See R. Noronha, "Paradise Reviewed: Tourism in Bali," in Tourism, Passport to Development? ed. E. de Kadt (New York: Oxford University Press, 1979), p. 201; and J. L. Maurer, Tourism and Development in a Socio-Cultural Perspective: Indonesia as a Case Study (Geneva: Institut Universitaire d'Etudes du Développement, 1979 ), p. 97.

${ }^{4}$ See,for example, E. Cohen, "Authenticity and Commoditization in Tourism," Annals of Tourism Research 15/3 (1988): 382; T. J. Macnaught, "Mass Tourism and the Dilemmas of Modernization in Pacific Island Communities," Annals of Tourism Research 9/3 (1982): 373-74; A. Mathieson and G. Wall, Tourism. Economic, Physical and Social Impacts (London: Longman, 1982), p. 166; P. L. Pearce, "Tourists and Their Hosts: Some Social and Psychological Effects of Inter-cultural Contact," in Cultures in Contact, ed. S. Bochner (Oxford: Pergamon Press, 1982), pp. 203-4.

${ }^{5}$ For a Western view of the Dutch conquest of Bali, see W. A. Hanna, Bali Profile. People, Events, Circumstances (1001-1976) (New York: American Universities Field Staff, 1976); and for a Balinese view, I. A. A. G. Agung, Bali Pada Abad ke-20. Perjuangan Rakyat dan Raja-raja Menentang Kolonialisme Belanda 1808-1908 (Yogyakarta: Gadjah Mada University Press, 1988).

${ }^{6}$ A. H. Vickers, Bali. A Paradise Created (Ringwood: Penguin, 1989). p. 91.

${ }^{7}$ On the Dutch colonial policy on Bali, see H. Schulte Nordholt, Bali: Colonial Conceptions and Political Change 1700-1940. From Shifting Hierarchies to 'Fixed Order' (Rotterdam: Comparative Asian Studies Programme Publications, 1986). 
Indonesian archipelago had its beginnings. In this year, the government opened an "Official Tourist Bureau" in Batavia, with the aim of promoting tourism in the Dutch East Indies. Initially focusing on Java, the Bureau was soon to extend its scope to Bali, then baptized in its brochures as "the Gem of the Lesser Sunda Isles."

By 1912 Netherlands rule was firmly established over the whole island, and in 1914 the military occupation force could be withdrawn and replaced by a police force. But it was not until 1924 that the Royal Packet Navigation Company (KPM) inaugurated a regular weekly steamship service connecting Bali with Batavia, Surabaya, and Makassar via the north coast port of Buleleng (Singaraja). Shortly thereafter, the KPM agent in Buleleng was appointed as the Tourist Bureau's representative on Bali, while the government began allowing visitors to use the official resthouses or pasanggrahan, originally designed to accommodate Dutch officials on their periodic rounds of the island.

In 1928 the KPM opened the Bali Hotel to replace the pasanggrahan in Denpasar, built on the very site of the puputan of 1906. Following this, the KPM also upgraded the pasanggrahan at Kintamani, which from then on was occupied by tourists who came there to enjoy the spectacular panoramas around Lake Batur.

The first tourists arrived in Bali either aboard a cruiser that berthed in Padang Bay for one or two days, or more commonly aboard the weekly KPM steamship that called at the port of Buleleng. Passengers on the KPM ships usually disembarked on Friday morning and departed on the same boat, returned from Makassar on Sunday evening, giving them just enough time to make a quick round of the island by car. The number of visitors increased steadily from several hundreds in the 1920 s to several thousands toward the end of the 1930s.

Among these visitors, special mention should be made of the small community of foreign residents-artists and anthropologists for the most part-which constituted a kind of avant-garde as well as a cultural asset for the elitist tourism which developed between the wars. The accounts, photographs, and films which recorded their stay on the island contributed to forging a brilliant image of Balinese society, an image which would be relayed through the promotional services of the nascent tourist industry. Since then, the island of Bali has consistently been described as the "last paradise" on earth, as a traditional culture whose bearers, endowed with exceptional artistic talents, devote a considerable amount of time and wealth to staging sumptuous ceremonies for their own pleasure and that of their gods...and now in addition for the delectation of foreign visitors. 8

Reading these accounts of between-the-wars Bali, one is struck by the fact that their authors were persuaded they were witnessing the swan song of a traditional culture miraculously preserved right up until then from the corrupting influences of modernity. In fact it is as if, since the "discovery" of the island by an avant-garde of artists and anthropologists during the 1920s, the mere evocation of Bali suggested the imminent and dramatic Fall from the "Garden of Eden," a state which the Balinese could not be expected to enjoy indefinitely. Indeed, one could surmise, with James Boon, that the appeal the island of Bali exerted over its visitors rests to a large extent on the premonition of the impending demise of its culture. ${ }^{9}$

\footnotetext{
${ }^{8}$ On the creation of the image of Bali as a paradise, see Vickers, Bali. See also Tessel Pollmann, "Margaret Mead's Balinese," above, pp. 1-35.

${ }^{9}$ See J. A. Boon The Anthropological Romance of Bali 1597-1972: Dynamic Perspectives in Marriage and
} 
Among the perils which threatened Balinese culture, the most conspicuous one was none other than the coming of the tourists themselves. Thus the ambivalent attitude evinced by the colonial authorities with respect to tourism. On the one hand, the cultural traditions of Bali were the major asset for the tourist promotion of the island. But, on the other hand, if the Balinese culture was to be preserved, measures had to be taken to protect it against the corrupting contact with the modern world brought about by the presence of foreign visitors to the island.

The landing of Japanese troops on Sanur beach in 1942 spared the Dutch government the necessity of determining a consistent tourist policy for Bali. In fact, until the late 1960 s tourism remained very limited on the island, potential visitors being dissuaded by the rudimentary state of the infrastructure, together with the political agitation and the xenophobic orientation of the régime that marked the period. Yet President Sukarno adopted Bali as his favorite retreat and made it a showplace for state guests. Eager to use the fame of the island to attract foreign tourists, he built the Ngurah Rai international airport in Tuban and undertook the construction of a prestigious hotel on Sanur beach, the Bali Beach Hotel, which was financed by Japanese war reparations. The hotel was to be inaugurated in 1966 at a moment when political unrest due to the Gestapu "coup" had closed Indonesia's doors to foreigners.

When General Suharto became President of the Republic in 1967, his "New Order" régime rapidly began reopening Indonesia to the West. These moves coincided with a period of high growth in international tourism, and from this time onward tourists started coming back to Bali in significant numbers. Such development was the direct result of a decision made by the government within the framework of the First FiveYear Development Plan (1969/1974) to promote international tourism, primarily in order to address a pressing national balance-of-payments deficit. Bali's prestigious image, formed during the prewar years, was crucial to the island being chosen as the focus of tourism development in Indonesia.

Accordingly, the government, heeding the advice of the World Bank, commissioned a team of French consultants to draw up a "Master Plan for the Development of Tourism in Bali." Their report, published in 1971 and revised in 1974 by the World Bank, proposed the construction of a major 425-hectare tourist resort at Nusa Dua (on the east coast of the Bukit peninsula, between Benoa and Bualu), and a network of roads linking the new resort with major attractions on the island.10 With the official promulgation of the Master Plan by Presidential Decision in 1972, tourism became a top economic priority in the province, second only to agriculture. Meanwhile, the number of foreign visitors rapidly multiplied from fewer than 30,000 per annum in the late 1960s to over 600,000 in the late $1980 \mathrm{~s} .11$

Caste, Politics and Religion (Cambridge: Cambridge University Press, 1977), p. 189.

10 See SCETO, Bali Tourism Study. Report to the Government of Indonesia (Paris: UNDP/IBRD, 6 Volumes, 1971); and IBRD/IDA, Bali Tourism Project. Appraisal Report (Washington: Tourism Projects Department, 1974).

${ }^{11}$ Suprising as it may sound, there are no reliable figures concerning the total number of "foreign tourists"that is, visitors who are not Indonesian citizens usually dubbed wisatawan mancanegara nowadays, as opposed to "domestic tourists," who are called wisatawan nusantara-visiting Bali. The only figures regularly published by the Bali Tourism Promotion Board (Diparda Bali) concern foreign tourists entering Indonesia directly via Ngurah Rai international airport, which numbered 360,415 in 1988 . To this figure one has to add the foreign visitors to Bali who entered Indonesia through another international airport, estimated as being about 60 percent of the direct arrivals, thus making a total of some estimated 574,000 foreign tourist arrivals in 


\section{"Cultural Tourism"}

Faced with this fait accompli and pressed to ratify the Master Plan, about which they had not really been consulted, the Balinese authorities insisted on profiting by the tourist trade, as well as on controlling its development. In reply to what they termed the "challenge of tourism" (tantangan pariwisata), the Balinese responded with the formula of "Cultural Tourism" (Pariwisata Budaya). The purpose and the outline of what was to become the tourist doctrine of Bali were officially adopted in October 1971, as the outcome of a "Seminar on Cultural Tourism in Bali" (Seminar Pariwisata Budaya Daerah Bali), jointly convened by the regional government and Balinese agencies for tourism, religion, and culture. ${ }^{12}$

The proceedings of this seminar reveal that the Balinese were perceiving tourism as being both fraught with danger and filled with the promises of forthcoming prosperity. Indeed, they were faced with a dilemma. On the one hand, the artistic and religious traditions which made the name of Bali famous the world over provided the main tourist attraction of the island. But on the other hand, the invasion of Bali by visitors originating from different horizons was seen as a threat of cultural "pollution" (leteh). By their exposure to foreign influences conveyed by the opening up of their island to international tourism, the Balinese incurred the risk of no longer being able to differentiate between their own values and those brought in by their visitors. This in turn-or so it was feared-would lead Balinese culture toward a "touristic culture" (budaya pariwisata), characterized by a confusion between the values of culture and those of tourism. ${ }^{13}$

The policy of cultural tourism was conceived as the only way out of this dilemma. It was expected to develop and promote simultaneously culture and tourism (pembinaan kebudayaan dan pengembangan kepariwisataan), by taking advantage of Balinese culture to attract tourists, while using the economic benefits of tourism to foster Balinese culture. ${ }^{14}$

One might surmise that the policy of cultural tourism has achieved its mission successfully, at least if one relies on today's declarations from the Balinese authorities

Bali in 1988. These figures do not take into account the steadily increasing numbers of domestic tourists visiting Bali-Indonesian visitors to the island were estimated by the Bali Tourism Promotion Board at around 300,000 in 1988. Official forecasts for the Fifth Five-Year Development Plan (1989/1994) are 1,300,000 foreign tourists in Bali by 1993, while hotel capacity should increase from 13,000 to 20,000 rooms during the same period.

${ }^{12}$ Hasil Keputusan Seminar Pariwisata Budaya Daerah Bali (Denpasar, 1971).

${ }^{13}$ One thus sees that, from the 1930 s to the 1970 s, the dilemma facing the authorities charged with designing a tourist policy for Bali has been defined in similar terms: tourism relies on culture, but tourism is a threat to culture. The main difference is that the Dutch wanted to preserve Balinese culture in what they saw as its "traditional" state, whereas the Balinese authorities had a much more dynamic view of their own culture.

${ }^{14}$ Once publicized, the formula of cultural tourism aroused impressive fervor among Balinese officials and intellectuals, becoming the inevitable reference for every discussion and every decision concerning tourism on the island. In this respect, it is significant that the slogan of cultural tourism has led not so much to the adoption of concrete measures which one could have rightly expected from what has been defined as a policy (Kebijaksanaan Pariwisata Budaya), but to a profusion of discourses whose argumentation composes the Balinese tourist doctrine. The authors of this doctrine, whom I refer to as the "Balinese authorities," besides including members of the provincial government, also include senior echelons of the regional administrative apparatus, the intelligentsia such as academics and journalists, people holding an official position, and finally, any opinion leader of sufficient reputation to be acknowledged as a public spokesman by the Balinese as a whole. 
attributing to tourism a "cultural renaissance" on the island. According to them, tourist money has revived Balinese interest in their own traditions, while stimulating their artistic creativity. And above all, the admiration of foreign visitors for Balinese culture is said to have reinforced the sense of cultural identity and pride of the people of Bali.

Such a conclusion accords with that expressed by a growing number of foreign observers, who willingly acknowledge nowadays that their former fears have proved groundless. ${ }^{15}$ Thus, while the French consultants who drew up the Master Plan predicted that, by 1985 , "the cultural manifestations will probably have disappeared,"16 today one commonly finds statements such as the following:

If anything, tourism has pumped more life into the Balinese cultural Renaissance that began earlier this century... There are probably more superb artists and craftsmen in Bali today than at any time in its history. With the infusion of dollars from tourist performances, village dance companies have been able to afford new costumes that inspire continual pride in their art. 17

Thus, the question which I pose is what has happened in the the intervening years now that tourism, formerly accused of being a cause of "cultural pollution," is extolled as an agent of "cultural renaissance"?18

\section{Cultural Performances as Tourist Attraction}

I shall attempt to answer this question by endeavoring to understand what happens to cultural performances when they become a tourist attraction. For this purpose I shall take up the problem precisely where McKean left it. His thesis has indeed the great merit

${ }^{15}$ In this respect, one cannot but be struck by the fact that the fear of an imminent debasement of Balinese culture evinced by between-the-wars observers is still expressed in a similar fashion in more recent accounts. Thus Willard Hanna was writing in 1976: "It is prudent, however, to point out that certain highly discriminating visitors of the 1920s and 1930s, who first made the island's magical charm well known to the outside world, warned even then that it was already too late for later comers to experience the real, the unspoiled Bali. It was not then in fact too late. It is not too late now. Given Bali's demonstrated capacity over the centuries for continuous and creative self-renewal, it still may not be too late in the year 2000. But a stampede by then of half a million tourists each year seems the formula for extinguishing, not rekindling the luminous culture which is Bali's glory" (Hanna, Bali Profile, p. XIII). But then, insofar as this apprehension of an impending demise of Balinese culture as a result of tourism has remained to this day, to the point that the prediction of its forthcoming downfall has been continually postponed since the $1920 \mathrm{~s}$, it gives way to the conviction that Balinese culture is more resilient than one could be led to believe in view of the changes occurring on the island since its opening up to international tourism.

${ }^{16}$ SCETO, Bali Tourism Study, vol.2, p. 161.

17P. Zach, "Bali: Paradise Preserved," International Herald Tribune, (July 25, 1986), p. 9. Statements such as this one remind us of what was already being written by Miguel Covarrubias in the 1930s: "Judging from old reports, it seems that there are more performances, the shows are more elaborate and varied, and there are many new styles besides that of the jealously preserved classic theatre" (M. Covarrubias, Island of Bali [1937, Reprint, Singapore: Oxford University Press, 1987], pp. 223-24).

${ }^{18}$ An indication of what happened is provided by the choice of vocabulary used by the Balinese authorities when making these statements. Although of course the doctrine of "Pariwisata Budaya" ("cultural tourism") was necessarily phrased in the national language, the word used for "cultural pollution" was "leteh," a vernacular term, whereas the slogan "cultural renaissance," which came into use a few years later, appeared in English. This double switch of language, first from Balinese to Indonesian with the use of Balinese terms to express key cultural concepts, and then their progressive replacement by English references, is a sign of a revealing shift of identity pointing to the fact that Bali has become more and more integrated within the Indonesian state as well as within the international tourist market. [To help the reader identify these different idioms, I have marked all Balinese cultural references with bold face characters, whereas I used italics for Indonesian and other foreign terms.] 
of discarding fruitless speculations, like "cultural pollution" or "cultural renaissance," in order to focus on an analysis liable to empirical assessment. It is clear in this respect that his argument-just like the Balinese doctrine of cultural tourism-stakes its validity on the capacity of the Balinese to maintain a distinction between those performances intended for themselves, and the attractions which are expressly designed to accommodate their foreign visitors. Thus the crux of the matter amounts to assessing whether the Balinese are actually in a position to discriminate between their cultural performances according to the audience for whom they are intended.

This approach is closely akin to that advocated by Edward Bruner, who states that "we must ask what the differences are between cultural expressions and performances designed for outsiders, as opposed to those designed for the people themselves." 19 In this approach, cultural performances are seen as the locus of an ongoing dialogue between tourists and locals, between the universalistic requirements of international tourism and the particularities of a given tourist destination. International tourism generates a demand for cultural performances by prompting whole societies to stage their culture for foreign audiences. In reply to this demand, the local populations construct a representation of their culture, simultaneously based upon their own indigenous system of references and their understanding of the tourists' expectations.

In this respect, the contemporary evolution of the Balinese performing arts certainly provides the best illustration of the problems raised by the conversion of cultural performances into tourist attractions. If the much celebrated Balinese dances indeed represent the trademark of this island to outsiders, one should not forget that dance is considered by the Balinese themselves as the yardstick of their artistic creativity par excellence. Furthermore, beyond providing entertainment for Balinese and tourists alike, these renowned dances, which have contributed so much to Bali's fame, function above all as a stage where Balinese society displays itself, where its members simultaneously enact and watch their own history and their own values: a stage which serves as a crucible where the Balinese celebrate their common participation in the same community. So much so that it is in connection with the performing arts that the question of how to discriminate between what the Balinese sell to the tourists and what they reserve for themselves-between their own cultural performances and the tourist attractions which are derived from them-arises with the utmost clarity.

I shall present my argument in two stages. First, I shall consider Balinese dance as a tourist attraction. I shall briefly describe the main genres of performances expressly designed for the entertainment of tourist audiences, while trying to assess how far they depart from performances held for the Balinese themselves.

Then, I shall discuss the Balinese responses to the "challenge of tourism." I shall pay attention successively to the way the Balinese authorities have perceived the problems posed by the conversion of traditional dances into tourist attractions, to the measures they have adopted to resolve these problems, and to the results they have achieved. After this, my remaining concern will be to examine with circumspection the claim of a "cultural renaissance" of Bali, by specifying what has to become of their culture for the Balinese to attribute its renaissance to tourism.

${ }^{19}$ E. M. Bruner, "Experience and Its Expressions," in The Anthropology of Experience, ed. V. W. Turner and E. M. Bruner (Urbana: University of Illinois Press, 1986), p. 28. 


\section{Balinese Dance as a Tourist Attraction}

Dance in Bali does not fit into the Western notion of "performing arts." To start with, there are no such terms as "art" or "artist" in the Balinese language. What we call "art" is for the Balinese a functional occupation, a service to the gods and community, a task which is always concrete and specific, executed by a "specialist." Thus a dancer is a "dance specialist" (juru igel), while a musician is a "music specialist" (juru gambel). And then, in Bali dance partakes of both theater and ritual. On the one hand, the terms in use-igel-igelan, ilen-ilen, sasolahan-refer to both the choreographic and the dramaturgic elements of a performance, which are not conceptually differentiated by the Balinese. ${ }^{20}$ On the other hand, as a requisite of most ceremonies, dance and drama are "not merely a spectacle to be watched but a ritual to be enacted." 21 The difficulty one faces when attempting to draw a dividing line between that which pertains to spectacle and that which belongs to ritual has been aptly expressed by Jane Belo, when she observed that the Balinese consider dramatic performances as an offering, whereas they stage the presentation of offerings like a performance:

in Balinese culture no very sharp line was drawn between the performance of ritual and dramatics; any dramatic performance was in itself an offering to the gods, and the presumption was that the better the performance, the better the gods would be pleased. ${ }^{22}$

Indeed, in Bali dramatic performances are not intended only for human audiences, because present among the spectators, invisible but nevertheless attentive, are the ancestors, the gods and the demons-who share with the Balinese a keen taste for lively festivals and fine performances. In this respect, dance is at once an offering to the gods and an entertainment for the people.

The traditional context for a dramatic performance is provided by the numerous religious celebrations (yadnya) which punctuate Balinese life: temple festivals (Dewa Yadnya), rites of passage (Manusa Yadnya), funeral ceremonies (Pitra Yadnya), practices of exorcism (Buta Yadnya), and so on. Nevertheless, while most dances are organically bound to a ceremonial occasion, they do not all partake of ritual to the same extent. This poses a problem of classification, which foreign observers thave tended to approach by sorting dance into the categories of the sacred and the profane, even though the authors of the first surveys of dance and drama in Bali had taken care to warn their readers against the fundamental inadequacy of principles of classification so radically foreign to Balinese reality. ${ }^{23}$

\footnotetext{
${ }^{20}$ For a detailed description of the various genres of dance and drama encountered in Bali, see B. de Zoete and W. Spies, Dance and Drama in Bali (1938, Reprint, Kuala Lumpur: Oxford University Press, 1973); M. Bandem and F. deBoer, Kaja and Kelod. Balinese Dance in Transition (Kuala Lumpur: Oxford University Press, 1981); and M. Bandem, Ensiklopedi Tari Bali (Denpasar: Akademi Seni Tari Indonesia, 1983).

${ }^{21}$ Clifford Geertz, "Religion as a Cultural System," in The Interpretation of Cultures (London: Hutchinson, 1973), p. 116.

22Jane Belo, Trance in Bali (New York: Columbia University Press, 1960), p. 115.

${ }^{23}$ See W. Spies and R. Goris, "Overzicht van dans en tooneel in Bali," Djawa 17 (1937): 205; and de Zoete and Spies, Dance and Drama in Bali, p. 46. Bandem and deBoer have attempted to construct their presentation of Balinese dances upon the indigenous classification kaja/kelod (that is "mountainward"/ "seaward"). However, as they linked the former with the sacred, the divine, and the good, while associating the latter with the demonic, the chthonian, and the evil, they ended up creating even further confusion (Bandem and
} 
At the risk of oversimplifying the situation for the sake of clarity, one could say that the main sources of patronage for dramatic performances are traditionally the temples (pura) and the courts (puri).

The temples are periodically activated during festivals (odalan), which is when a congregation establishes contact with the gods associated with their temple. These deities are invited to descend among the congregation and to take their place on the shrines dedicated to them. When seated, they are urged to participate in the ceremony and to attend the spectacles presented in their honor. In this respect, one should distinguish between performances held in the temple while a ceremony is in progress, and performances held outside the temple in the evening following a ceremony.

The courts, and more specifically the ruling Rajas, were-and still are to a certain extent today-accountable for the staging of large-scale ceremonial spectacles, aimed at attesting the links with deified ancestors, as well as at propitiating supernatural forces. Deemed crucial for the sake of the realm and the welfare of its subjects, these court rituals provided an opportunity for the princes to vie with each other in munificence, by displaying their capacity to mobilize men and wealth in the service of their glory and that of their ancestors. To this end, the princes supported troupes of dancers and musicians, either at the palace or in neighboring villages. Moreover, they were often themselves accomplished dancers, and it was not infrequent for them to take part in the performances they organized.

The loss of the power of the courts and their-relative-impoverishment following the Dutch occupation of Bali reduced their capacity to organize spectacular ceremonies. Progressively, the princes ceded the disposal of their musical instruments and dance costumes to the villagers. Though perhaps detrimental to the classical theater, this decline of court patronage did stimulate artistic creativity in the villages, where new musical and choreographic styles were invented.

With the war and the subsequent struggle for independence, followed by a period of political unrest and economic hardship, the spectacles and ceremonies went through critical times. After such a period of financial and artistic depression, the development of tourism in the late 1960s undeniably provoked a stimulation of the performing arts by providing a constantly renewed public willing to pay a good price to see the famed dances of Bali. If the demands of tourism are largely responsible for the increasing number of performances noticed at that time, one must emphasize that the coming of the tourists coincided with a renewed interest in the Balinese arts on the part of the Indonesian government. So much so that the present situation of dance and drama in Bali reflects the combined influence of this double patronage, between which it is sometimes difficult to distinguish clearly.

Government exerts its patronage and influence in a number of ways. Of particular importance here are several institutions established to teach, preserve, and promote Balinese artistic traditions-specifically the performing arts: the Conservatory of Music (Kokar), the Academy of Dance (ASTI), the Arts Council (Listibiya), and the Art Center (Werdi Budaya). ${ }^{24}$ In some respects, these institutions have taken over the role formerly

deBoer, Kaja and Kelod, p. VIII). On this question, see the review of their book by M. Picard, in Archipel 31 (1986): 215-18.

${ }^{24}$ The Conservatory of Music (Konservatori Karawitan Indonesia, Kokar), was founded in 1960 through the initiative of a few Balinese artists. Later on it became the High School of Music (Sekolah Menengah Karawitan Indonesia, SMKI), to be placed under the formal responsibility of the Department of Education and Cul- 
exercised by the courts-creating styles and establishing norms for their execution, training dancers and musicians, and organizing and financing performances. With the difference, which is crucial, that, contrary to the courts which were always careful to maintain their own distinctive styles, the Indonesian government is deliberately centralizing, normalizing, and standardizing the Balinese performing arts.

Moreover, inasmuch as Bali is a province of the Republic of Indonesia as well to an international tourist destination, Balinese arts have become means to other ends, being nowadays expected both to foster the development of tourism in Indonesia and to contribute to the development of the national culture. Hence, the government is banking on the prestige that Indonesia gains in foreign eyes through the systematic promotion of Balinese performing arts, and it furthers the creation of artistic forms and media displaying a marketable image of Bali. Balinese dance has become in fact one of the prime assets of the "artistic missions" (misi kesenian) which are regularly sent abroad as the spearhead of Indonesian "cultural diplomacy" (diplomasi kebudayaan). Thus, artistic promotion becomes a tool of tourist promotion, as evident for example in the manifesto delineating the mission attributed to the Arts Council, which recommends that the government "pay heightened attention to the development of Balinese artistic traditions in order to secure the prosperity and the continuance of the tourist industry." 25

\section{Tourist Performances}

The arrival of the tourists in Bali has provided a new audience for Balinese cultural performances-whether they be ceremonies which the visitors happen to attend or attractions intended specifically for their entertainment-to the extent that tourism has placed the Balinese in the novel situation of having to interpret their culture for a foreign audience.

The tourist performances occur either in the home village of the troupes, where the tourists are brought by busloads (Batubulan, Bona, Peliatan), or in international hotels where they are generally presented during dinner (Sanur, Nusa Dua). An intermediary type is provided by the troupes originating from the tourist resorts of Ubud, Kuta, or Sanur, who hold regular performances for the tourists residing in their villages. Generally speaking, the troupes who perform for the tourist market also perform for the Balinese audience in ceremonial contexts. They are concentrated in the districts of Gianyar and Badung, the main tourist areas on the island.

Except for the groups performing in tourist resorts, the most pressing problem which faces a troupe willing to perform for the tourists is its difficulty in gaining direct access to the market. The performers are thus dependent on commercial intermediaries, who are

ture.

The Academy of Dance (Akademi Seni Tari Indonesia, ASTI) was created in 1967 and was integrated into the Department of Education and Culture in 1969. Its name has recently been changed into the College of Arts (Sekolah Tinggi Seni Indonesia, STSI).

The Arts Council, officially called the Consultative and Promotional Council for Culture (Majelis Pertimbangan dan Pembinaan Kebudayaan Daerah Propinsi Bali, Listibiya), was established in 1966 through the initiative of a group of officials, artists, academics, and professionals with the task of preserving and promoting Balinese arts.

The Art Center (Werdi Budaya) was opened in 1976 by the Department of Education and Culture, with a view to promoting Balinese arts.

25 "Pembinaan Seni Budaya perlu lebih mendapat perhatian dari Pemerintah demi kelangsungan serta kelanggengan industri pariwisata itu sendiri" (Listibiya, Pola Dasar Kebijaksanaan Pembinaan Kebudayaan Daerah Bali [Denpasar, 1973], p. 7). 
able to manipulate the competition between the different troupes and impose their own conditions, not only financially, but also in terms of the presentation of the spectacle and even the details of its program. The tickets are sold for between two and five dollars, and the troupe divides its receipts according to different criteria, one portion remaining in the troupe's collective account, the other being divided among its members, who receive between fifty cents and two dollars per performance. A troupe's collective receipts are used primarily for the maintenance of its equipment, for the celebration of ceremonies in which it participates, for contributing to communal expenses, and for the taxes on performances which are levied by the district administration.

These tourist performances involve between two and three thousand dancers and musicians according to the Arts Council, which is the agency in charge of controlling the artistic productions for the tourist market. In order to maintain a high standard, the Balinese authorities have decided that no troupe will be allowed to perform for tourists without a "Certificate of Art" (Pramana Patram Budaya) delivered by the Arts Council, and this holds true also for groups hired to perform abroad.

The performances regularly staged for the tourists last between an hour and an hour and a half, which is short in comparison with the performances held for the Balinese, which can continue for five hours or more. Their schedule varies from every day to once a week, and they take place either around nine in the morning, or in the evening between six and eight. They are presented either on a raised platform facing the audience seated on chairs or on a stage surrounded by tiers of seats. Inevitably the decor represents the entrance to a temple, thus authenticating the aesthetic event which the spectators are invited to attend. Most of the time, when a tourist performance is held in a village, it attracts Balinese spectators, who stand behind the tourists and watch the spectacle for free.

Given the extraordinary diversity of dances encountered in Bali, one cannot but be struck by the uniformity of the performances presented to the tourists. Most of them derive from one of four main genres, which in turn fall within two clearly distinct categories. On the one hand, visitors are invited to attend spectacles originally conceived as entertainment. On the other, acknowledging the fascination of foreigners for possession trance, the Balinese offer them performances wherein the dramatic character of ancient rites of exorcism is deliberately exploited. 26

\section{"Legong Dance"}

It is not without significance that the arrival of the first tourists in the early $1920 \mathrm{~s}$ was contemporary to the artistic revolution of the Kebyar, whose major result was to separate dance from its dramatic content as well as from its ritual context, thus convert-

\footnotetext{
${ }^{26}$ One notices that these two categories of tourist performances, the dance and the trance, correspond to the two sides of the touristic image of Bali established in the 1930s: the diurnal and the nocturnal, the Apollonian poise and the Dionysian frenzy. Behind the gentle figure of the young dancing girl lurks the horrible figure of the old witch-the "Island of the Gods" is also the "Island of the Demons." See Vickers, Bali. A Paradise Created, p. 105.
} 


\section{MUSIC AND DANCES OF BALI

\author{
THE CLASSICAL LEGONG DANCE \\ OF PELIATAN
}

EVERY SATURDAY

Time: $180^{\circ}-19.30$

A: : PELIATAN (U bud)

I. OVERIUR E, Instrumental only.

II. GABOR / PENDET :

This dance is similar to the Pendet dance and has only been recontly included in the Iegong performance. It is notually a religious dance porformed at temple ceremonies by malo and lemale pemangkus (priests) womop. and young girls. While dancing they took the offering to the diffrent shrines. in the temple. In the Legong ferformance this dance is done by two or wore girls. Every one of them hold a silver bowl of flowers. The girls male proying ces tures and towards to the end the dance they throw the flowers to the audien ce. This Is meant to pay homage to the public and bless them at the somer time.

III. BARIS:

A worriors dance, both functioning at temple ceremonials and performed ns characters on the Balinese stage in dance and drama.

IV. KEBIAR TEROMPONG :

This dance is similar to tho Febiar Duduk dance. The greator part of this dance is performed in a sitting position. This dance purely an orranent.ul. dance in which the dancer. joins the orchestra by playing the instrunent Ierompons. This dance is created by the famous choreographer the late lix. Wario.

V. LAGONG KARATON ; (accompaniod by Semara Pegulingan Gamelan Husic).

This is a classical dance tabing its story from a historical rounnco based on actual event taking placo in the 12 th and 13 th centuries $A . \Omega$.

The elrst charocter to be seen on the stage is Tjondung (a court lady). The two Legongs representing the prince Lasem and princess Ranglissari appar on the scece. The real story begins after the Tjondong has handed tho fans to each of the Logon6s. Lasom has forcibly carried of Rangkesari of Dalh. Despite his efforta, she persistently refuses to yield to hir, monn whice she learns that the erowiprince of Kahuripan to whom sho betrothed is couling is to her resque. Feeling sorry to hor abductor, Rangkesari uncesLasom to set her free. Hovever he would sooner to meet and confron: the cromprince than to return her to him. On his way to the battle, Insem romes aeross araven, an indication of a bad omen. Paying no hoed to the ineident, Lasem after chasing the bird away, proceed and in the fight he is lilled by the crownprince. The fight is not to be on the stage.

VI. SEMARA. PEGUIINGAN (INSTREATIMAI ONLY).

Serara meant love and Pegulingan meant bed. In the former days this musie was played while the King and his wife were making love in bed.

VII. OLEG TAMBULILINGAN :

This dance depicts a flirtation act between two bumble bees a male and female while sucking honey in a beautiful flower garden. They fly werrily

from flower to flowers and so enjoying themselves. At the end of the daneo both of the bees fallin love to each othor.

VIII. MASK DANCP:

IX. Instrumental only.

M.B.: Please note the order of the program is some times changed deponding on the readiness of the dancers. 
ing it into a form of independent entertainment. ${ }^{27}$ Freed of the constraints which hindered its development until then, Balinese dance was made accessible to spectators ignorant of linguistic codes, dramaturgic conventions, and literary references. Above all, dance had to become autonomous before it could be treated as a product to be exploited at will for commercial ends.

This new style rapidly became popular with the tourists. They were presented with a spectacle composed of a series of short dances in Kebyar style, first by the Dutch management of the pasanggrahan in Denpasar, and then every Friday evening at the Bali Hotel, where a pavilion was especially built for this purpose. This spectacle remained fundamentally unchanged until the war. It was revived and standardized further in the late 1960 s by the management of the Bali Beach Hotel in Sanur, which used to present it around the swimming pool as dinner entertainment.

The coming of tourists thus greatly stimulated the creation of "free dance" performances (tari lepas, also called tarian bisu, that is, "mute dances"). These dances are "free" in the sense that they are detached from any tie of a dramatic or ritual nature, and just follow each other in a haphazard fashion. Some were removed from their original theatrical context to be transformed into solo dance (Baris, Topeng, Jauk), some were originally designed for the tourists (Panyembrama, Oleg Tamulilingan), while others are abridged and simplified versions of court dances (Legong Keraton), or modern Kebyar compositions (Kebyar Duduk, Taruna Jaya, Panji Semirang). These performances, nowadays rigorously standardized, were readily dubbed "Legong Dance," even if they did not conserve anything of the original Legong except its name. ${ }^{28}$

For someone familiar with dance and drama in Bali, it seems fairly obvious that such a program would not make much sense to a Balinese audience. ${ }^{29}$ And yet, performances of "Legong Dance" have proved popular with the Balinese, and they are frequently presented in the context of temple festivals.

${ }^{27}$ First witnessed around 1915 in Buleleng, the Kebyar was initially a kind of musical piece played on the large ceremonial gamelan gong gede. The aim was to display the virtuosity of the musicians with extremely fast and complex rhythms, full of sudden stops and starts. Later on, a new orchestra-the gamelan gong kebyar-considered more appropriate to the new musical style, was created, while dances were designed, to render its rhythms in a choreographic fashion. In fact, the advent of the Kebyar attests to the birth of a tendency to reject the ancient norms which tied specific dances to specific musical accompaniments and dramatic forms. Whereas formerly each particular genre of dance or drama entailed resorting to a different kind of orchestra, the popularity of the Kebyar style now tends to prescribe the use of the gamelan gong kebyar for most occasions, while the more specialized orchestras have fallen into disuse, whether they be just forsaken or deliberately recast. See C. McPhee, Music in Bali (New Haven: Yale University Press, 1966), p. 328.

${ }^{28}$ Probably the most celebrated of all Balinese dances, the Legong-also called nowadays Legong Keraton, or "Court Legong" - dates back to the early nineteenth century, and its choreography combines elements borrowed from a twofold tradition. On the one hand is the Sanghyang Dedari, an old exorcistic dance performed by two little girls in a trance state, and on the other, the Gambuh, the prototype of all the genres of court theater, most likely originating from Java. From the Sanghyang to the Legong via the Gambuh, one can discern a movement toward the creation of a purely aesthetic dance, detached from all ritual function or dramatic content, and refined to suit the taste of the nobility. The Legong then spread to the villages and was influenced by the Kebyar, which replaced the gamelan pelegongan by a gamelan gong kebyar, speeded up its tempi, and modernized its choreography. Its subsequent presentation to the tourists reduced the length of its performance from over an hour to a mere fifteen minutes, while most of its former eighteen versions fell into disuse to the quasi-exclusive benefit of the Legong Lasem.

${ }^{29}$ Witness the comment of I Made Bandem, Director of the Academy of Dance: "To the Balinese audience, this is akin to a meal consisting entirely of appetizers" (Bandem and deBoer, Kaja and Kelod, p. 149). 
SUMMARY OF TIE RAMAYANA EPIC :

For the sake of his beloved parents, Dasarata who crowned Barata as king of Ayodia Rama the legal heir to the throne, left his father's palace followed by his wife sita, and his faithful. younger brother, Laksamana. After wandering around for while, they came to a forest called Dandaka. Rawana, the king of Alengka desired to kidnap Sita and ordered his Minister Maritja to transfom him self into a golden deer to allure Rama. By using this trick. Rawana succeeded in kidnaping sita.

While on their way to Alengka encountered by a huge eagle, Djatayu who was a friend of Rama. Djatayu tried to recapture Sita with all his might but Rawana was too powerful for him and he was seriously wounded.

After Rama and Laksamana heard Djatayu's explanation about the kidnapping of Sita by Rawana they continued their journy to Alengka. Some where along the way they came across twin brother monkeys, king sugriwa and subali, cuelling with each other By Rama's help, sugriwa defeated his brother Subali. Sugriwa thanked Rama for his help and ordcred Hanoman to assist Rama in finding his wife. Hanoman succeded to meet sita at the Fark of Alengka. Having done his duty, Hanoman destroyed the Park there by causing a great chaos to the people. of Alengka.

Accompanied by an all monkey troop, Rama and Laksamana attacked Alengka. A great battle accuŕcd between Rama and Rawana which ended with Rama's victory. Finally sita met her loving husband and joyfully they returned to Ayodia:
I. SITA-RAMA-IJAKSAMANA-KIDJANG EMAS (GOLDEN DEER)

Sita and Rama in loving mood followed by Laksamana are in the forest of Dan daka. After a while, a golden deer appears. Sita and Rama try to catch it but in vain. The deer goes away and Sita asks Rama to chase it, Rama leaves Sita with Laksamana.

\section{SITA - LAKSAMANA}

Sita hears a cry for help which she thinks is Rama's. She asks Laksamana to go and help biat he refuses because he believes that Rama is an invincible king. Sita forces him to go and accuses him of waiting for Rama's death so he could marry her. Laksamana then goes away leaving sita alone without any protection.

III.P R I E S T - S I T A

A priest appears and asks sita for some water Sita welcomes him but after a while the priest disappears and a mighty Rawana comes out and kidnaps Sita:- Rama and Laksamana reappear Rama angrily asks Laksamana where Sita is and he has left her. Laksamana tells Rama about sita's accusation and asks his forgivenees. Then Rama and Iraksamana set out in search of sita.

IV. DJATAYU - RAWANA - SITA

On their way to Alengka Rawana and Sita are encountered by a mighty eagle called Djatayu. Djatayu attacks Rawana trying to free sita.

unfortunately he is defeated by Rawana

\section{SUBALI-SUGRIWA-RAMA-LAKSAMANA}

On their way to rescue sita, Rama and Laksamana come across Sugriwa fighting with his brother Subali. By Rama's help Sugriwa succeeds in defeating his brother subali.

\section{HANOMAN-RAMA-LAKSAMANA}

Hanoman the Commander of the monkeys appears. Rama sends him to Alengka.He gives him ring asks token to be shown to sita.

\section{SITA-TRIDJATA-DAJANG-DAJANG (LADIES-IN-WAITING) - HANOMAN}

Sita is now in Rawana's palace bemoan ing her misfortune. She is accompanied by Tridjata (Rawana's niece), Rawana appears forcefully asks sita to Jove him. Sita vigorously refuses and Rawana becomes angry. He want to kill sita but is prevented by. Tridjata.

Rawana cisappears and Hanoman emerges showing sita Rama's ring in order to convince her that he is Rama's messenger. Before lcaving llanoman is attack ed by some demons who guard the palace of Rawana.

VIII. RAMA - T,AKSAMANA - RAWANA

Rama fights Rawana

Rama comes outs as winner.

IX. RIMA-SITA-LAKSAMANA-HANOMAN

Rama is reunited with sita, beloved and victoriously they returned to Ayodia. 
In this respect, the fate of the short group dance which opens every performance of "Legong Dance"-whether destined for tourists or for the Balinese-is revealing. It was originally a temple dance, called the Pendet, performed by dancers presenting welcoming offerings of flowers, food, and incense to the visiting gods installed on their shrines. During the 1950s, it became the rule to greet President Sukarno and important state guests with a large-scale Pendet. This custom was then taken up by the management of the Bali Beach Hotel, which decided to open each "Legong Dance" with a Pendet, as a welcome dance for their guests. This caused great distress to the Balinese religious authorities, shocked that the tourists were being treated in the same way as the gods, and worried about the desecration of ritual dance. Thus, in the late 1960s, they ordered the composition of a new dance inspired by the Pendet from a choreographer of the Conservatory of Music. Entitled Panyembrama (literally "that which is offered to the guests") or else Tari Selamat Datang ("welcome dance"), this new creation from then on replaced the Pendet as a curtain-raiser to the tourist performances. Later on, this tourist version of a temple dance was brought back to the temple, as dancers who had learned the Panyembrama at the Conservatory began to perform it instead of the Pendet during temple festivals.

\section{"Ramayana Ballet"}

Inspired by European ballet, the "Ramayana Ballet" was modeled on the spectacle of the same name created in 1961 by a prince from Surakarta (Java)-then Minister of Communications and Tourism-in the amphitheater constructed in front of the temple of Loro Jonggrang at Prambanan. The idea was to design a spectacle suited to a nonJavanese audience, unfamiliar both with the language and the dramaturgic codes of Javanese court theater. Called Sendratari-an acronym composed from the roots seni: "art," drama: "theater," and tari: "dance" - this new form was adapted to Balinese taste a year later by the same choreographer who was to create the Panyembrama, to celebrate the first anniversary of the Conservatory. Composed in Kebyar style and based on the Balinese legend of Jayaprana, the new spectacle was an immediate success. But it was not until 1965 that the Sendratari became an acknowledged genre in Bali, with the creation at the Conservatory of the Sendratari Ramayana by the same author. In this novel version of the Ramayana, the complete story narrated in the epic was presented in an abridged fashion, by retaining only its main episodes, reduced to a bare outline in order to fit them in a single performance.

To appreciate how far the Sendratari departed from established standards, one has to know a few things about theater in Bali. In Balinese theater, the plot of a "story" is secondary, to the point of being almost unimportant, in the sense that a dramatic performance does not relate the lineal unfolding of a literary theme from its inception until its final denouement. Instead, it consists of a succession of discrete scenes, composed of a combination of independent elements, juxtaposed one after the other. While being subjected to a precise codification, the progress of a particular story is left to the free improvisation of a set of attendant characters answering to the generic name of panasar or parekan.

The role played by these characters is rendered necessary by the particular nature of literature in Bali. The Balinese have at their disposal a composite literary repertoire, depicting the mythical kingdoms of the Indian epics, the Javanese empire of Majapahit, and the Balinese rajadoms which succeeded it. The characters, circumstances, and atmosphere distinctive of these different realms are evoked through distinct literary genres. And these literary genres in turn are composed in distinct but interrelated idioms, 
which the Balinese are accustomed nowadays to grouping together under the generic term of kawi-usually translated as "poetic language." The main consequence of this contemporary multiplicity of idioms is the fact that it necessitates translation and paraphrase. Indeed, for the Balinese, literature is not a fossilized product fixed by the circumstances of its writing, but it is, on the contrary, a constantly actualized process. A text is destined not to be read but to be sounded in a literary session, that is, first to be recited (papaosan) by a "narrator" (juru paos), then to be translated and paraphrased in vernacular (bebasan) by a "commentator" (juru basa). ${ }^{30}$

For the Balinese, theater is the main vehicle for the sounding of the texts which compose their literary heritage. Particular religious and artistic contexts determine which literary tradition is to be referenced and specify, consequently, the dramatic genre which is to be performed. But whatever the dramatic genre under consideration, the distinctive structure of Balinese literature, composed of a text written in an archaic idiom and of its paraphrase extemporized in vernacular, requires the presence on stage of two distinct groups of characters. The characters of the first group-ancient gods and demons, legendary priests and kings-belong to the past as depicted by a literary tradition. They constitute, as it were, the structural equivalent of the juru paos during a literary session. as they express themselves in kawi. Their behavior is stereotyped and conforms strictly to the dramaturgic and linguistic conventions which govern their literary referent. The primary function of the characters of the second group, who take the part performed by the juru basa, is to convey the teachings of the gods and ancestors in a language comprehensible to a contemporary audience. Dancing back and forth between the characters of the past on the one hand, between the world of the text and the world of the present on the other, these characters perform the role of mediators. Being both retainers and advisers of the nobility, under the guise of simple commoners or even grotesque buffoons, they enjoy considerable liberty of expression, interpreting the utterances and conduct of their masters in a burlesque manner and criticizing them whenever they feel like it. But at the same time, they are responsible for expounding the moral of the play, as well as for delivering various messages of the authorities, to the audience. $^{31}$

These mediators-the panasar-always come in pairs, generally two brothers, or a father and his son. The elder, called panasar kelihan or Punta, is a bombastic fellow, full of self-importance. The younger, the panasar cenikan, also named Kartala or Wijil, never misses a chance to ridicule the exploits of his elder. Whereas the panasar kelihan is imbued with the majesty of his master and bound to the world of the past by word and gesture, the panasar cenikan moves freely between the past and the present, being the spokesman for the common people and their problems. ${ }^{32}$

As mediators, the panasar actualize the values of the past-those values depicted by

${ }^{30}$ On literature in Bali as "the sounding of the texts," see J. S. Lansing, The Three Worlds of Bali (New York: Praeger, 1983); R. H. Wallis, "The Voice as a Mode of Cultural Expression in Bali" (PhD dissertation, University of Michigan, 1979); and M. S. Zurbuchen, The Language of Balinese Shadow Theater (Princeton: Princeton University Press, 1987).

${ }^{31}$ On the place of the panasar in Balinese theater, and specifically in wayang, see Angela Hobart, "Between Things: The Place of the Pandasar in Bali," Archipel 25 (1983): 159-70.

${ }^{32}$ On the way the panasar weave the past and the present together, creating a theatrical space between the world of the text and that of the audience, see J. Emigh, "Playing with the Past. Visitation and Illusion in the Mask Dance of Bali," The Drama Review 23/2 (1979): 11-36; and N. Kakul, "Jelantik Goes to Blambangan; a Topeng Play," ibid: 37-48. 
Indian epics, Javanese court etiquette, and the perennial wisdom of the Balinese ancestors-by constantly placing them in new contexts, thus investing them with a contemporary relevance. So much so that, thanks to their presence, Balinese theater has proved to be a form of cultural performance which can accommodate new messages while preserving the old. One could even go further and claim that, by helping Balinese audiences to make sense of new meanings and to integrate them without becoming estranged from their cultural heritage, the panasar account in no little manner for the exceptional faculty of selective adaptation that most foreign observers accredit to the Balinese culture. Furthermore, because of their ability to articulate conceptually distant universes-past and present, foreign and indigenous, noble and common, literate and vernacular, written and oral-the panasar provide the Balinese with a constantly renewed commentary on their society, endowing it with that specific reflexive character which observers find so intriguing.

In any case, it should be clear by now that the distinctive feature of Balinese theater-which allowed it to withstand time by retaining an undiminished appeal to contemporary Balinese audiences-rests on the dynamic balance between the stylized evocation of a literary tradition and its parodic counterpoint provided by the panasar. One is in a better position then, fully to appreciate the significance of the upheaval brought about by the advent of the Sendratari onto the Balinese stage. Unlike traditional theater, which elaborated on a literary theme well known to the audience and constantly renewed according to the inspiration of the panasar, the Sendratari relates a complete story made up of successive episodes strung together in a linear fashion until their denouement. In this new genre, instead of having the dancers speak their lines in kawi, and then having the panasar paraphrase them in Balinese, a narrator (juru tandak), sitting with the musicians, comments on the plot, using alternatively kawi and Balinese, while the dancers pantomime the action on stage. The main outcome of this innovation is the fact that it renders superfluous the mediating function traditionally performed by the panasar, reducing them to a subordinate position of attendants to principal characters. ${ }^{33}$

Another innovation of paramount importance consecrated by the Sendratari-and taken up by the Drama Gong-is the adoption of a Western-style stage facing the audience (panggung). This innovation, which goes back to the theater constructed on the campus of the Conservatory, is a complete departure from the traditional conception of a stage in Bali. Called a kalangan, the Balinese stage is a rectangular area surrounded by a

33 It is certainly no coincidence that, precisely when the panasar were losing ground in the Sendratari, their inclination for parodic mimicry and farcical buffoonery was finding an outlet in a new dramatic genre, the Drama Gong. Created in 1966, during the aftermath of the Gestapu, the Drama Gong appears in many respects to be the exact reversed image of the Sendratari. Initially based on the same literary themes, it treats them in a very different manner by giving up the choreography for the sake of clowning and melodrama. So much so that, by forsaking the conventional stylization for a realistic and largely improvised interpretation, the contrast between the main characters and the panasar is becoming blurred. Thus, even though the panasar are regaining prominence, their primary function has vanished since all the characters express themselves in Balinese, which is, moreover, heavily interspersed with Indonesian. Today it is as if all the elements of traditional theater ousted from the Sendratari were to be found in an exaggerated fashion in the Drama Gong, to the exclusion of all the others. But what these two genres have in common is the disruption caused by the disappearance of the function performed until then by the panasar. Whether they are reduced to a subordinate position as attendants in the Sendratari or, on the contrary, given a heightened importance as clowns in the Drama Gong, the panasar can in any case no longer take on their role as mediators because of the weakening of the dialogic polyphony that used to be the distinguishing feature of Balinese theater. 


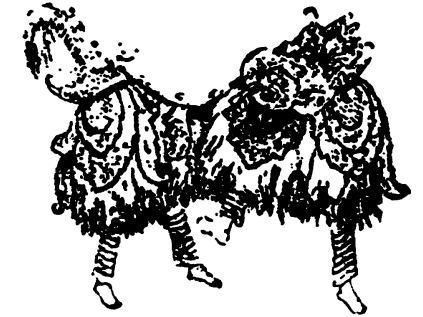

THE BARONG AND KRIS DANCE

The Barong - Play represents an eternal fight between good and evil spirit. B a r o n (a mythological animal) represents a good spirit and Rangda (a mythological monster) represents an ovil one.

THE DANCE STARTS WITH MUSIC OVERTONE

Followed by his friend the monkey, the tiger comes up. Three masked-dancers appearr representing men making palmwine in the forest, whose child is killed by the tiger. The three men get angri and attack the tiger which is helped by the monkey. During the fight the nose of one of the three men is bitten off.

FIRSTACT

Two girl-duncers appear, representing the servants of the Rangda, looking for the servants of Dewi Kunti who are on the way to meet their Patih (Prime Minister)

\section{PEMAKSAN BARONG DENJALAN BATUBULAN - GIANYAR - BALI}

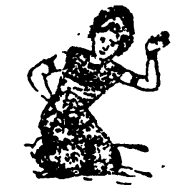

SECONDACT.

The servants of Dewi Kunti come. One of the servants of the Rangda changes into a witch enters both servants to make them angry They. meet thier Patih and go together to Dewi Kunti.

T H I R D A C T

Dewi Kunti and her son, Sadewa come up. Dewi Kunti has promised the Rangda to sicrifice Sadewa. A witch appears and enters Dewi Kunti. She becomes angry and orders the Patin to bring Sadewa into the forest. The Patih is olso entered by a witch so be does not have pity on Sadewa.

Sadewa is then taken into a forest and tied up on tree.

FOURT HACT

Unknown by the Rangda, God Siwa appears and gives Sadewa immortality the Rangda appears, ready to kill Sadewa and eats him up but Sadewa is still alive. She then surrenders and asks him to redeem herself, Sadewa agrees and kills tha Rangda. The Rangdil goes into Heaven.
F I F T H A C T.

One of the servants of the Rangda called Kalika comes up bepore Sadewa and asks him to redeem herself too Sadewa repuses. Katika gets angry, and change berself into boar and fights Sadewa. The boar can be defeated. She then changes berself into a bird but defeated again. At last she changes herself into a Rangda. Sadewa cannot kill her. In such circumstanses Sadewa meditates and then be changes himself into a Barong. Still the Rangda seems 10 be 100 powerfi Still the Rangda seems to be 100 pow and the fight is unended. Follower of the
Basong appear and helf him figtt the Rangda

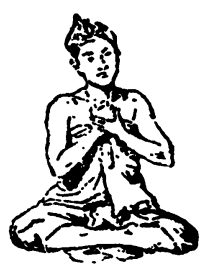

Tharok you very much 
foot-high bamboo fence which delineates the boundaries of the performing space. The spectators watch the performance from three sides, while the musicians are diversely disposed according to the kind of orchestra they are playing. Always temporary, a kalangan may be set in the courtyard of a temple or a palace, on the square of a village, or near a cemetery, depending on the circumstances of the performance. This spatial arrangement determines the traditional form of Balinese choreography (pedum karang), which is three-dimensional and describes a 8-shaped pattern, whereas in Sendratari or in Drama Gong-as well as in most Kebyar creations-the dancers facing the audience are being restricted to a two-dimensional space.

Since the 1960s, many a literary theme has been turned into a Sendratari, and this new dramatic genre is nowadays the most popular-along with the Drama Gong-with Balinese. As for the Sendratari Ramayana proper, one could say that, under the name of "Ramayana Ballet," it has become a genre in its own right. The prototype conceived at the Conservatory rapidly spread to the villages, where it has been regularly performed since. This success with the Balinese audiences marked out the "Ramayana Ballet" to become a standard tourist performance. Somewhere along the line, the juru tandak was eventually disposed of, thus taking the Sendratari even further away from Balinese theatrical conventions.

\section{"Barong and Kris Dance"}

This performance sprang from the lively interest shown by the first visitors for the masked figures of Rangda and Barong. Most descriptions of these two mythical figures have been expressed in terms of a never-ending confrontation between a destructivemalevolent "witch" and a protective-benevolent "dragon," between "black magic" and "white magic," thus stressing the conflict between a "negative" and a "positive" principle. There is ground to consider that such an interpretation owes more to a Western frame of reference-the conflict "good-versus-evil" - than to the view held by the Balinese, for whom it might be "not a question of good or evil, rather an issue of power, of like challenging like, a basic principle of Tantric magic, of establishing a rapport with the fearsome but ambiguous demonic." 34

Why would the Balinese seek to establish such a rapport with the demonic? Essentially because they see their life and well-being as depending upon the intervention of supernatural forces, which can be invoked and placated through the proper enactment of ritual procedures. In the case of Rangda and Barong, we are dealing with what Barbara Lovric calls "cult demonic deities," who are at once destructive and protective, in the sense that they are seen simultaneously as the creators of epidemic diseases and the agents of their prevention-or, at least, of their containment. The masks which symbolize them are considered sakti ("magically powerful" and, therefore, dangerous), meaning that, through a series of consecration rituals, they are able to bring about the transformation of an artifact into a vehicle of a supernatural force. ${ }^{35}$

\footnotetext{
34B. J. A. Lovric, "Balinese Theatre: A Metaphysics in Action," ASAA Review 12/2 (1988): 42.

${ }^{35}$ On Rangda, Barong, and the notion of sakti, see Jane Belo, Bali: Rangda and Barong (Seattle: University of Washington Press, 1949); Trance in Bali (New York: Columbia University Press, 1960); J. Emigh, "Dealing with the Demonic Strategies for Containment in Hindu Iconography and Performance," Asian Theatre Journal 1/1 (1984): 21-39; B. J. A. Lovric, "Rhetoric and Reality: The Hidden Nightmare. Myth and Magic as Representations and Reverberations of Morbid Realities" (PhD dissertation, University of Sydney, 1987); and R. Rickner, "Theatre as Ritual: Artaud's Theater of Cruelty and the Balinese Barong" (PhD dissertation, University of Hawaii, 1972).
} 


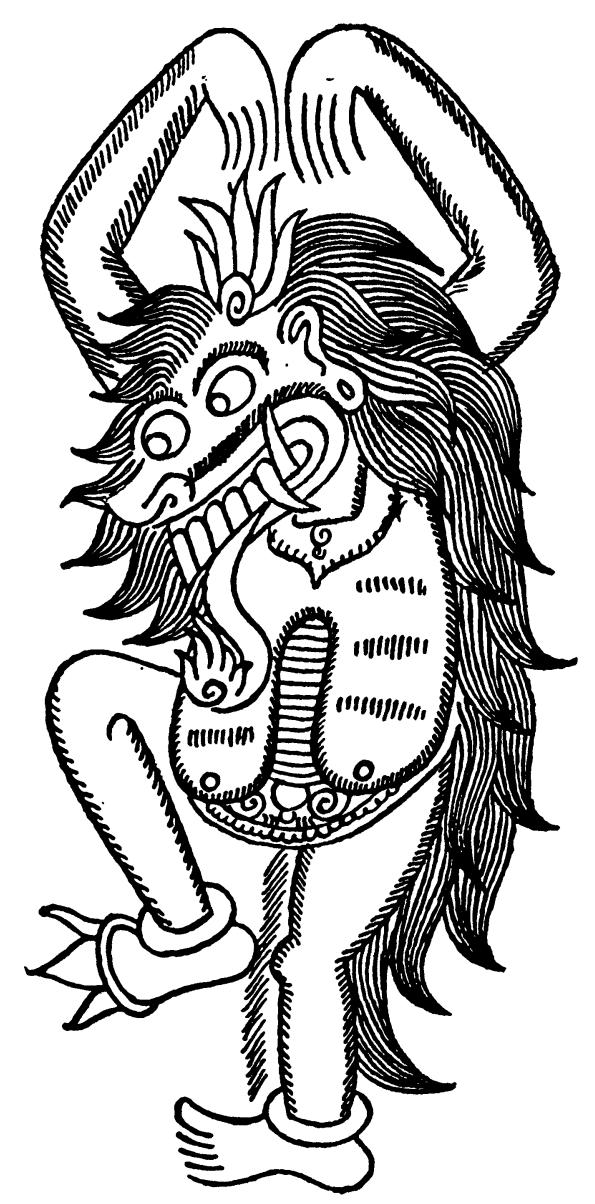

Rangda (from a Balinese Manuscript)

The Rangda mask is a receptacle for the power of Durga which, given appropriate deference and offerings, will protect the community from epidemic diseases. The mask has also the power to control leyak, people who, through the study of magic of the "lefthand path" (pangiwa) and a special affiliation with Durga, have acquired the power to transform themselves and to spread epidemic diseases.

The Barong mask is encountered in several animal forms. The most common and powerful one, known as Barong Ket, does not represent any particular animal but bears a close resemblance to the Kala-Boma image, a protective symbol which adorns gateways and other sites of transition. A fantastic mythical monster animated by two men, the Barong Ket is paraded through the village, stopping at the gates of each houseyard, after the festival of Galungan. This protective ritual, called ngalawang, is meant to control the buta kala, lesser demonics which are potential agents of diseases.

Sometime last century, Rangda and Barong confronted each other in a dance drama based on an Old Javanese historical legend of devastating pestilence, the Calonarang. ${ }^{36}$ For the Balinese, a performance of Calonarang is an exorcistic ritual, a magical means of preventing and containing epidemics. Such a performance is enacted in a space beset with supernatural forces (tenget), at mystically significant times (kala ala ayu), it makes

${ }^{36}$ See R. Ng. Poerbatjaraka, "De Calon Arang," Bijdragen tot de Taal-, Land-en Volkenkunde 82/1 (1926): $110-80$. 
use of magically powerful (sakti) paraphernalia, and it evokes characters and events which are clouded in secrecy (pingit). Moreover, it is considered crucial to the successful completion of the ritual that the wearer of the Rangda mask becomes possessed (karauhan) by its spirit, as this is an indication that Durga is actually participating in the ritual and is, therefore, protecting the community.

The most spectacular part of this dance drama, the confrontation of Rangda and Barong, involves a group of "followers" of the Barong being possessed by buta kala, who rush out to attack Rangda with their krisses but are subjugated by her power and stab themselves in a fit of suicidal violence (ngurek).

One can imagine that such a spectacle would not go unnoticed by foreigners in search of the sensational. An excerpt of the Calonarang-making use of masks which had not been ritually consecrated-was presented at the 1931 Colonial Exhibition in Paris, by dancers from Singapadu. A few years later, Jane Belo initiated a study of trance in Bali, to which were associated Margaret Mead and Gregory Bateson, the American dancer Katharane Mershon, and the most influential of the foreign residents of between-the-wars Bali, the German painter and musician Walter Spies. ${ }^{37}$ They documented especially the Barong troupes from Denjalan, Pagutan, and Tegaltamu, located in Batubulan, near the village of Singapadu. They commissioned special "kris dance" performances, not just for academic documentation, but also for personal entertainment. Unlike ritual enactments of Rangda and Barong, which occur generally at night, these performances were held during the day, so that they could be photographed and filmed. In 1936, notably at Spies' instigation, the troupes of Denjalan and Pagutan started competing for the fame and profit of organizing commercial performances of Calonarang in honor of distinguished visitors. That same year, the dancers from Singapadu, spurred by the success of their rivals of Denjalan and Pagutan, decided to organize commercial performances themselves. They contacted a guide who agreed to bring tourists to their village, providing that the plot would be modified so as to be easier understood by a foreign audience. Thus a new spectacle was devised by the famous dancer I Made Kredek, based on the Javanese exorcistic tale of Sudamala, better known in Bali as Kunti Sraya. ${ }^{38}$ Cutting dialogues to a minimum and adding some slapstick humor, this spectacle was called "Barong and Kris Dance."

Interrupted by the war, the performances of "Barong and Kris Dance" were put on again in the 1960 s by the troupes from Batubulan and Singapadu. Since then, this is the version which has been presented to tourists, in particular in Batubulan, where today no less than three troupes perform it simultaneously for an hour each morning. ${ }^{39}$

\section{"Monkey Dance," "Angel Dance," and "Fire Dance"}

These spectacles have their roots in trance exorcistic dances called Sanghyang, traditionally enacted in order to contain epidemics. According to Barbara Lovric, these trance dances

\footnotetext{
37 See Belo, Bali: Rangda and Barong; and Trance in Bali.

${ }^{38}$ See P. van Stein Callenfels, "De Sudamala in de Hindu-Javaansche Kunst," Verhandelingen van het Bataviaasch Genootschap van Kunsten en Wetenschappen 66 (1925): 1-181.

${ }^{39}$ See A. E. Sanger, "Blessing or Blight? The Effects of Touristic Dance-Drama on Village Life in Singapadu, Bali," in The Impact of Tourism on Traditional Music (Jamaica Memory Bank, 1988), pp. 89-104; and N. L. Suci, "Pariwisata dan lakon pertunjukan Barong di Desa Batubulan," Pengkajian Budaya 3/1 (1977): 27-36.
} 
REPRESENTATIVE OFFICE

DENPASAR - TEL. : 5504

\section{WARGA SEKEHE KECAK BONASARI BONA - GIANYAR}

\section{KECAK OR MONKEY DANCE.}

KECAK IS THE MOST UNIQUE BALINESE DANCE WHICH IS NOT ACCOMPANIED BY ANY ORCHESTRA/GAMBELAN BUT A CHOIR OF HUNDRED OF MEN. IT HAS ITS ORIGINE IN AN OLD RITUAL DANCE "SANGHYANG" OR TRANCE DANCE. IN THE SANGHYANG DANCE A PERSON IN A STATE OF TRANCE COMMUNICATES WITH THE DEITIES OR ANCESTORS. USING THE DANCERS AS A MEDIUM THE DEITIES OR ANCESTORS CONVEY THEIR WHISES. IN 1930's THE OLD INDIAN EPIC RAMAYANA WAS INCLUDED INTO THE DANCE.

BRIEFLY THE STORY RUNS AS FOLLOW :

DUE TO AN EVIL TRICK PRINCE RAMA THE LEGEL HEIR TO THE THRONE OF AYODYA WAS EXILED FROM THE REALM OF HIS FATHER DASARATA. ACCOMPANIED BY HIS WIFE SITA AND HIS YOUNGER BROTHER LAKSMANA THEY WENT INTO A FOREST CALLED DANDAKA. WHILE THEY ARE IN THE FOREST THE DEMONS KING RAHWANA FOUND THEM AND LUST AFTER THE BEAUTIFUL SITA. ACCOMPANIED BY HIS PRIME MINISTER MARICA, THEY MAKE A TRICK TO STEAL SITA. USING HIS MAGIC POWER MARICA TRANSFORM HISSELF INTO A GOLDEN DEER. DISGUISE AS A GOLDEN DEER THEY SUCCEED INCLURING RAMA AND LAKSMANA AWAY FROM SITA. RAHWANA MAKES USED THIS OPPORTUNINY KIDNAPPED SITA AND TAKE HER TO HIS PALACE ALENGKA. DISCOVERING THE DECEPTION RAMA AND LAKSMANA SET OUT TO RESCUE SITA FROM THE CLUTCHES OF THE DEMONS KING. ASSISTED BY THE HUGE ARMY OF MONKEYS UNDER THE COMMAND OF THEIR KING SUGRIWA SUCCEED IN DESTROYING RAHWANA'S ARMY UNDER THE COMMAND OF HIS SON MEGANADA, FINALLY RAMA SUCCEED IN GETTING HIS WIFE BACK SAVE AND SOUND.

SOME EPISODE OF THIS EPIC ARE REPRESENTED IN THESE FOLLOWING

ACT : ACT 1. RAMA, SITA AND THE GOLDEN DEER.

RAMA, SITA AND LAKSMANA ENTER THE ARENA.THEN AGOLDEN DEER APPEARS SITA ASKS RAMA TO CATCH THE DEER FOR HER. RAMA LEAVES SITA UNDER LAKSMANA'S PROTECTION. SOON A CRAY FOR HELP IS HEARD. SITA THOUGHT THAT WAS THE VOICE OF RAMA AND SENDS LAKSMANA TO HELP HIM. AT FIRST LAKSMANA REFUSED TO LEAVE HER ALONE. BEING ACCUSED OF EXPEC. TEING RAMA'S DEATH SO THAT HE CAN MERRY HER LAKSMANA GETS SO ANGRY AND LEAVE HER ALONE.

ACT. 2. SITA AND RAHWANA. RAHWANA APPEARS ǨIDNAPPED AND TAKES SITA TO HIS PALACE ALENGKG

ACT. 3. SITA, TRIJATA AND HANOMAN.

ACCOMPANIED BY TRIJATA RAHWANA'S NIECE SITA BEMOANING HER MISFORTUNE IN THE GARDEN OF RAHWANA'S PALACE. HANOMAN ( A WHITE MONKEY) APPEARS. HE TELLS SITA THAT HE IS RAMA'S ENVOY AND SHOWS HER RAMA'S RING. SITA GIVES HIM HER HAIRPIN TO BE TAKEN TO RAMA WITH A MESSAGE THAT SHE WAITING FOR RAMA'S RESCUE.

ACT. 4. RAMA, MEGANADA AND GARUDA.

IT REPRESENTS RAMA IN THE BATTLE FACING MEGANADA, RAHWANA'S SON. MEGANADA SHOT RAMA WITH HIS MAGIC ARROW WHICH TURNS INTO A DRAGON TIES RAMA UP AS WITH A ROPE. IN HIS DESPERATION HE CALLS FOR GARUDA HIS ALLY. GARUDA APPEARS AND RELEASES RAMA FROM THE DRAGON.

ACT. 5. RAMA, SUGRIWA AND MEGANADA.

SUGRIWA THE KING OF THE MONKEYS APPEARS. SOON A FIGHT BETWEEN SUGRIWA AND MEGA. NADA ENSUES. THE PERFORMANCE IS ENDED BY THE VICTORY OF RAMA'S SIDE. FINALLY RAMA, SITA, LAKSMANA RETURN HOME HAPPILY.

\section{SANGHYANG DEDARI DANCE.}

SANGHYANG DANCES DEVELOPED FROM THE ESSENTIAL RELIGIUS FUNCTION OF MAINTANING THE HEALTH AND WELL-BEING OF THE VILLAGE. THEY ARE PERFORMED TO DRIVE EVIL SPIRITS AWAY BE INFESTING THE COMMUNITY IN THE FORM OF SICKNESS OR DEATH.

DESCRIBED HERE IS SANGHYANG DEDARI, A RITUAL DANCE WHERE IT IS BELEIVED A DEVINE SPIRIT TEMPORA. RILY DECENDS TO A VILLAGER AND REVEALS IT SELF TROUGH THE ENTRANCED DANCER. SANGHYANG IS THL TITLE A DEVINE SPIRIT AND MEANS "HOLINESS"

DEDARI MEANS "ANGELS" AND DESCRIBES THE TRANCE CEREMONY. DANCE BY TWO LITTLE GIRLS AND ARE ALWAYS UNDERAGE, FOR A VIRGIN CHILD IS CONSIDERED HOLY. IN THE SANGHYANG, WHERE THE DANCERS PUT INTO TRANCE PRIOR TO DANCING, THE CEREMONY BEGINS IN THE TEMPLE AND PROCESSION IS PORMED TO MARCH TO THE PLACE WHERE IT WILL TAKE PLACE. SET UPON THE GROUND BETWEEN THE FEMALE CHOIR AND MALE CHERUS, THE LITTLE DANCERS SWAY FREELY IN A DREAMYVERSION OF THE LEGONG.

THEIR MOVEMENT COINCIDE OUTOMATICALLY, ALTHOUGH THEIR EYES NEVER OPEN DURING THE ENTIRE PERFORMANCE. WHEN THE CHANTING STOPS, THE GIRLS JUMMP TO THE GROUND. THEY ARE BROUGHT OUT OF TRANCE BY THE PEMANGKU, WHO PRAYS BESIDE THEM AND BLESSES THEM WITH HOLY WATER.

\section{SANGHYANG JARAN DANCE.}

AN ENTRANCED BOY DANCES ON A HORSE (JARAN) BEHAVING LIKE A HORSE. HE DANCES AROUND A BON. FIRE MADE FROM COCONUT HUSK.

IF THE SANGHYANG SONG LEADS HM TO THE FIRE, THEN HI WILL DANCE ON THE FIRE. 
function as spirit-raising seances in which the spirits of diseases are invoked, invited to participate, are cajoled and then dismissed. Contact or participation is achieved through trance possession. The desired exorcism is contrived and realized by simulation of the destructive powers of the causative agent; by enacting an image of its potentiality and thereby reducing its effectiveness. ${ }^{40}$

There are numerous kinds of Sanghyang, of which the two most common are the Sanghyang Dedari and the Sanghyang Jaran. ${ }^{41}$

The Sanghyang Jaran belongs to the category of animal Sanghyang, in which the trance dancer "becomes" (nadi) the spirit of the animal invoked in the exorcism and mimics its behavior. The Sanghyang Jaran (or "Horse Sanghyang") prances astride a hobby horse and trots back and forth through the glowing embers of burning coconut husks, kicking the red hot coals with his bare feet. Enacted by one or several men, the Sanghyang Jaran is accompanied throughout by a male chorus called cak.

The Sanghyang Dedari owes its name to the widyadhari of Hindu mythology, although it is doubtful that they are actually the possessing spirits invoked in the ritual. It is enacted by two pre-pubescent girls, addressed as Sanghyang, who are traditionally not trained dancers. The Sanghyang are carried on palanquins or on men's shoulders around the village, stopping at magically critical sites, such as crossroads and bridges. After this procession, the Sanghyang are carried back to the temple to which they belong, where they dance to the alternate accompaniment of a chorus of women (juru kidung) and of men (juru cak). According to the local tradition of the village where it takes place, the dance can be borrowed from various repertoires, generally the Legong or, occasionally, the Calonarang. After the performance, the Sanghyang bestow "holy water" (tirta pamastu) or list remedies for ailing members of the community. When the ritual is over, the possessing spirits are dismissed and requested to go home.

From the cak chorus used in Sanghyang Dedari was created the Kecak. According to the famous dancer I Limbak, from Bedulu, sometime at the end of the 1920s he started incorporating Baris movements into the role of the cak leader. Walter Spies liked this innovation and suggested that he should devise a spectacle based on the Ramayana, accompanied solely by the cak chorus in lieu of the usual gamelan. And when in 1931 Spies was asked by Baron von Plessen to be an adviser on his film "Insel der Demonen," which was mostly shot at Bedulu, he reworked the Kecak to increase its dramatic impact. If the new spectacle was an instant success among Spies' circle of friends and visitors, it seems that it failed to attract the interest of the Balinese. In any case, it soon became known by the tourists under the name of "Monkey Dance," referring to the singers sitting in concentric circles playing the part of the monkey army sent by Prince Rama to rescue his wife Sita.

In the late 1960s, the Kecak was influenced by the "Ramayana Ballet," at the initiative of former students of the Conservatory who had returned to their native villages. The narrative, which up until then had been limited to one single episode of the Ramayana, was extended to encompass the whole epic tale, as in the Sendratari. The choreog-

${ }^{40}$ Lovric, Rhetoric and Reality, p. 387.

${ }^{41}$ See G. Ng. Bagus, "Sangiang Dedari dan Sangiang Jaran; sepintas uraian tentang upacara penyembuhan dan penolak bala di Bali," Pengkajian Budaya 3/2 (1977): 86-94; Belo, Trance in Bali; Lovric, Rhetoric and Reality; and R. M. G. S. O'Neill, "Spirit Possession and Healing Rites in a Balinese Village" (MA thesis, University of Melbourne, 1978). 
raphy, the melodies, and the costumes were modified accordingly. These innovations actually revived the popularity of the Kecak as a tourist performance, and they were enforced by the travel agents, who urged the performing troupes to conform to the new style.

One of the most famous Kecak of the 1930s had been the one performed in the village of Bona, not far from Bedulu. When tourism started booming anew in the early 1970s, the Kecak of Bona had lost its former reputation, due to the competition of new troupes as well as to the standardization of the spectacles presented to the tourists. In order to attract visitors, some villagers decided to revive their Sanghyang, which had fallen into disuse due to the eradication of the epidemics which they were supposed to contain. Thus, they added a Sanghyang Dedari and a Sanghyang Jaran-respectively called "Angel Dance" and "Fire Dance" - to their regular Kecak performances, and today, this spectacle is presented at Bona four times a week by two different troupes. The success met by this initiative has inspired groups at the beach resorts of Kuta and Legian to put on similar performances for their guests. But it is interesting to note that at Camenggaon as well as at Ketewel, in the vicinity of Bona, where the Sanghyang Dedari is still used in a ritual context today, the priests and the villagers were adamant in their condemnation of its being performed for commercial gain.

\section{Performances for the Balinese and Performances for the Tourists}

This brief survey of the main genres of tourist performance clearly illustrates the multiple interferences between the performances intended for the Balinese and the ones expressly destined for the tourists.

The "Legong Dance" and the "Ramayana Ballet" are modern creations, originally conceived as mere entertainment and deliberately designed to appeal to a foreign audience. Willingly received by the Balinese, they occupy now a place of honor in their habitual repertoire.

As for the performances of "Barong and Kris Dance" on the one hand, and of "Monkey Dance," "Angel Dance," and "Fire Dance" on the other, we are dealing with spectacles derived from rites of exorcism, each of them having evolved in a different way. Besides making an appearance in tourist performances, the figures of Rangda and Barong are used for exorcistic purposes, as well as in performances of Calonarang, which have a ritual significance for the Balinese. The Kecak was originally part of a ritual, but it rapidly became entertainment exclusively performed for foreign audiences. Then, the Sanghyang Dedari and the Sanghyang Jaran, which are still used for exorcistic purposes in some villages, have been recently adapted in other villages as a tourist attraction.

Finally, the short welcoming dance which opens every performance of "Legong Dance," the Panyembrama, has gone through the complete cycle from rite to entertainment and back to ritual use. Here we have a temple dance, the Pendet, which, due to the risks of desecration entailed by its being performed out of context, has given way to a secular version. Now adapted to commercialization, this new dance ended up back in the temple, being presented as an offering to the gods in lieu of the ritual dance proper.

Thus, if one could conclude that the conversion of Balinese dance into a tourist attraction has tended to disrupt the former relations between its ritual and its spectacular dimensions-which, as we have seen, are traditionally very difficult to differentiateone notices that such a disruption has not led to uniform results. The tari lepas and the Sendratari pertain to the general Balinese trend which tends to sever dance from its 
dramatic content as well as from its ritual context. The very fact that the Balinese themselves have adopted these tourist spectacles for their own entertainment in turn furthers this tendency. At first sight, the tourist performances exploiting the spectacular character of Rangda and Barong seem to contribute to the dissociation of theater and ritual, but at the same time they blur the issues. Finally, the commercialization of Sanghyang and Pendet has resulted in the turning of a Balinese ritual into a tourist entertainment.

\section{Balinese Responses to the "Challenge of Tourism"}

This confusion between ritual and entertainment is precisely what the Balinese authorities would not tolerate. Their reaction consisted of attempting to prevent the risk of "profanation" (provanasi) entailed by the "commercialization" (komersialisasi) of ritual dances, by endeavoring to work out criteria to distinguish between those dance genres which might be commercialized for the tourist market, and those which should not. While this question has been hotly debated for some years, today it is no longer at the center of public discourse. Instead, after having been accused of debasing Balinese religious values (mendegradasikan nilai-nilai agama), tourism is now regarded as a stimulus for artistic creativity and is celebrated for its alleged contribution to the "cultural renaissance" of Bali.

Rather than recounting in detail the evolution of the attitude adopted by the Balinese authorities in response to the problems posed by the conversion of cultural performances into tourist attractions, I shall focus on the two events which best illustrate this evolution, namely the "Seminar on Sacred and Profane Dance" held in 1971, and the annual "Bali Arts Festival" launched in 1979.

\section{The Seminar on Sacred and Profane Dance}

In March 1971-a few months before the publication of the "Master Plan for the Development of Tourism in Bali" and the organization of the "Seminar on Cultural Tourism" - the Balinese Office of the Department of Education and Culture (Kanwil Departemen P dan K Propinsi Bali) convened a "Seminar on Sacred and Profane Dance" in Denpasar (Seminar Seni Sacral dan Provan Bidang Tari). ${ }^{42}$

The issues addressed by this seminar were based on a twofold consideration. On the one hand, the Balinese-and especially those who are involved in the tourist industry-need precise directives so as to avoid being tempted to "touristify" (menoriskan) all forms of artistic expression, without paying any attention to their traditional function. On the other hand, the tourists have to know that the Balinese are not willing to "prostitute" (melacurkan) each one of their cultural traditions for the sake of commercial gains. These considerations dictated the aim ascribed to the seminar, which was thus formulated: to separate "sacred art" (seni sacral) from "secular art" (seni provan), and to distinguish between different genres of sacred art in order to determine which ones could be "secularized" (boleh di"provan"kan) and which ones should "keep their sacred character" (harus tetap di"sacral"kan). ${ }^{43}$

${ }^{42}$ Proyek Pemeliharaan dan Kebudayaan Daerah, in Seminar Seni Sacral dan Provan Bidang Tari (Denpasar, 1971).

${ }^{43}$ N. Tusan, "Uraian Pimpinan Sidang Pembukaan Seminar Seni Sacral dan Provan Bidang Tari," in ibid., p. 1. 
This proved to be a very delicate task indeed, judging by the confusion of the participants, a select group of Balinese officials and intellectuals requested to write a paper on that topic. They readily confessed their embarassment when asked to separate the sacred from the profane in matters pertaining to dance. This difficulty is not really suprising, bearing in mind that the Balinese language does not have at its disposal the terminology which would permit its speakers to articulate the opposition between these two concepts. In fact, as in any official meeting, the seminar was conducted in Indonesian, a language which has no terms for "sacred" and "profane" either. Consequently, the organizers had to resort to neologisms borrowed from Latin languages, namely "sacral" and "provan," for the title of that seminar. ${ }^{44}$

This semantic borrowing resulted in uneasy attempts to create a distinction which was in fact alien to the Balinese. Hence, two participants, and important ones at that, unable to understand the proposed terms of reference, decided to look for further clarification in their Dutch dictionary, which led them to commit a revealing misinterpretation. There they found the terms "sacra" and "prove," whose meaning was given respectively as "heilige voorwerpen" (that which lends something a holy or consecrated character) and "liefdegave" (that which characterizes a gift expressing love or compassion). Consequently, they mistook the terms "sacral dan provan" as referring to the same kind of dances. Stating this, they continued throughout their respective papers to talk about "sacred and profane dances" as a single category, which they defined as "those dances offered during a ceremony as an act of worship and purification." 45

Such is the "challenge" which tourism has imposed on the Balinese. Not only are they requested to slice the living substance of their culture in order to forge a dividing "boundary" (batas) where only a continuum existed, but furthermore, they are compelled to use a terminology which makes no sense to them. In their perplexity they see no other way out, except to resort to the vocabulary of their former colonial masters. Thus they seek in alien conceptual categories the means to rescue their most valued traditions from what they see as a risk of "acculturation" (akulturasi) brought about by the penetration of foreign visitors on their island.

Now, other participants of the seminar, lacking the concepts required to deal with the question of the sacred and profane, attempted to transpose it to more familiar ground, that of agama ("religion") and of adat ("tradition"). ${ }^{6}$ This is the case, in par-

\footnotetext{
${ }^{44}$ When attempting to know the reasons for resorting to the terms "sacral" and "provan" to entitle the seminar, I received the answer that this decision had been imposed by the Department of Education and Culture in order to widen the discussion by assigning it an importance at once "national" and "scientific." Moreover, some of its organizers willingly admitted that the choice of an alien terminology had been considered necessary because the younger generation could no longer understand the meaning of the traditional Balinese terms. Whatever the veritable reason, the fact remains nonetheless that by deciding to treat their dances in the terms of the opposition between the sacred and the profane, the Balinese officials of Culture and Religion were repeating the same mistake common to foreign analysts, a mistake already exposed as we have seen by Spies and Goris in 1937, as well as by de Zoete and Spies in 1938.

45'Tarian itu dipersembahkan didalam hubungan upacara adat dan agama yang mengandung unsur-unsur pemujaan dan penyucian" (G. B. N. Pandji, "Prasaran mengungkap tari-tarian sacral dan provan yang ada di Bali," p. 1 in Seminar Seni Sacral dan Provan Bidang Tari); see also G. B. Sugriwa, "Prasaran Seni Sacral dan Provan berdasarkan filsafat," p. 1, in Seminar Seni Sacral dan Provan Bidang Tari.

46 In Indonesia the term agama (of Sanskrit origin) officially defines "religion," considered to be universal and monotheistic, whereas adat (of Arabic origin) applies to "tradition," understood in the sense of the ways and customs handed down from the ancestors. The problem is that in Bali not only do these terms originally bear a rather different meaning, but even more so, their respective semantic fields overlap considerably. The Balinese-Indonesian dictionary issued by the Regional Board of Education attests to this, witness the entry
} 
ticular, of the Head of the Balinese Office of the Department of Religion (Kakanwil Departemen Agama Propinsi Bali). Acknowledging the difficulty in discriminating clearly between that which belongs to agama and that which pertains to adat in Bali, this official attempted to solve the problem by separating from adat anything which in fact falls within the domain of agama. This portion of adat he termed "religious tradition" (adat keagamaan), to distinguish it from what he considered as merely "customary tradition" (adat kebiasaan). In that way, he produced a new semantic classification where agama, augmented by adat keagamaan, is opposed to adat, now a residual category no longer possessing any scope beyond that relating to adat kebiasaan. 47

The outcome of this conceptual restructuring is that the former significance of adat as an all-encompassing order-cosmic as well as social-has been relativized and secularized by being deprived of its religious aura. Once secular, adat can be converted into tourist attractions, thus regaining in aesthetic qualities what it has lost in religious prerogatives, and eventually being celebrated as "art" (seni budaya). ${ }^{48}$

Now, why is it so important for the Balinese authorities to separate the "sacred" from the "profane"? This dichotomization should be seen as a two-edged process. On the one hand, inasmuch as they perceived tourism as a threat of "destruction" (kehancuran) coming from abroad, the Balinese attempted to find firm ground on which to stand. This standing ground was to be their "religion" (agama), conceived as the "foundation" (sendi), the "cornerstone" (landasan), the "root" (pangkal), the "core" (inti), the "essence" (sari), of their "Balineseness" (kebalian). 49 Thus, agama had to be set apart from mere customary usage (adat), seen in this respect as "peel" (kulit), which could be either discarded in case it displeased the tourists or, conversely, commercialized on the tourist market if it appealed to the visitors' taste.

word "agama," which refers among other meanings to "adat" (W. Warna, Kamus Bali-Indonesia IDenpasar: Dinas Pengajaran Propinsi Daerah Tingkat I Bali, 1978], p. 29. Actually, adat is for the Balinese a truly religious notion, in the sense that it refers both to an immutable divine cosmic order as well as to a social order instituted in conformity with the former.

${ }^{47}$ G. A. G. Putra, "Tari-Tarian Sacral dan Provan dari Segi Rituil," p. 1, in Seminar Seni Sacral dan Provan Bidang Tari.

${ }^{48}$ This evolution of the significance of the term adat is not limited to Bali, as testified by the research carried out by Susan Rodgers Siregar on the Batak of Sumatra, as well as that of Greg Acciaioli and Toby Volkman on the Toraja of Celebes. See G. Acciaioli, "Culture as Art. From Practice to Spectacle in Indonesia," Canberra Anthropology 8, 1 and 2 (1985): 148-74; Susan Rodgers Siregar, "Advice to the Newlyweds: Sipirok Batak Wedding Speeches. Adat or Art?" in Art, Ritual and Society in Indonesia, ed. E. M. Bruner and J. O. Becker (Athens: Ohio University, 1979) pp. 30-61; and T. A. Volkman, "Great Performances: Toraja Cultural ldentity in the 1970s," American Ethnologist 11/1 (1984): 152-69. An interesting selection of essays on the relations between adat and agama in various Indonesian societies is found in Rita S. Kipp and Susan Rodgers eds., Indonesian Religions in Transition (Tucson: The University of Arizona Press, 1987).

${ }^{49}$ The idea that religion is the cornerstone of Balinese culture and society goes back to colonial times. As political power changed hands, religion became one of the key foci of Balinese life. Inasmuch as the Dutch pretended to preserve Balinese culture, they had to set apart religion, which was left to the Balinese aristocracy, from politics, which was the prerogative of the colonial government. This distinction, although alien to Balinese reality, was indeed welcomed by the aristocracy, who saw it as a means to reassert their power. Yet, in those days, religion still meant traditional order, and had not yet been separated from adat. Thus a dichotomization was established between a religious domain, pertaining to customary authorities (adat), and a secular domain, coming under the jurisdiction of administrative authorities (dinas, from the Dutch dienst). On these questions, see Schulte Nordholt, Bali: Colonial Conceptions and Political Change; and Vickers, Bali. A Paradise Created. 
On the other hand, the carving out of a realm of the "sacred," defined as the domain of agama, is a strategy for the Balinese to circumscribe a stronghold and have it recognized by the Indonesian government. 50 This is the strategy adopted by the Parisada Hind $u$ Dharma, an organization endeavoring to reform the religious beliefs and practices of the Balinese population in the direction of a more orthodox Hindu brand of monotheism, so as to have them admitted to the rank of agama-just like Islam or Christianity-by the Indonesian Department of Religion. ${ }^{51}$

Thus we see that the official Balinese response to the "challenge of tourism" furthers the movement of religious rationalization which is taking place on the island. How does this "disenchantment of the world" (Entzauberung) express itself in Bali? Even though it is difficult to obtain consistent evidence in this respect, it seems one can discern a general tendency to reduce the ambiguity traditionally attached to manifestations of the supernatural. This tendency strives to dissociate conceptually that which belongs to religion from that which pertains to magic, the divine from the demonic, or perhaps more correctly, that which is endowed with a supernatural power (sakti, tenget, pingit, and so forth) from that which is ritually consecrated and purified (suci). Such a trend is well illustrated by the growing inclination of the Balinese-especially those whose profession it is to explain their culture to the tourists-to interpret the conflicts staged in theater in terms of good (kebaikan) and evil (keburukan), that is to say isolate ethics as a principle in its own right. This is particularly the case in the dramatic confrontation between Barong and Rangda, where an univocal moral judgment is more frequently substituted for the morally ambiguous notion of sakti. ${ }^{52}$ This despite the

\footnotetext{
${ }^{50} \mathrm{~A}$ recent example of such a strategy is provided by the reaction of the Balinese authorities to the prohibition of cockfights (tajen) by the Indonesian government in 1981. Unwilling to renounce the practice of tajen altogether, the Balinese were compelled to discriminate between that which they thought should be retained as ritual obligation (tabuh rah) and that which could be discarded as being only a pretext for gambling (judi). In order to do so, they transposed the issue in terms of a distinction between agama and adat, conceived as an opposition between "what is conceptual" (yang bersifat konseptional) and "what is traditional" (yang bercorak tradisional). They perceived the problem as the result of a "mixing" (pembauran) between the teachings of agama and the dispositions of adat. And they tried to solve it by "sifting out" (menyaring) what, in adat, was in accordance with the precepts of agama, from what was running against these precepts. See M. Picard, "En feuilletant le Bali Post: à propos de l'interdiction des combats de coqs à Bali," Archipel 25 (1983): 171-80.

${ }^{51}$ Even though it dates back to the colonial period, the movement of religious reformism in Bali has taken shape in response to the obligation expressed by the Pancasila (the "Five Principles" of the Indonesian state) to belong to a monotheistic religion, as well as in reaction to Islamic expansionism in the archipelago. In the 1950s, statements were worded by Muslim leaders to the effect that Balinese religion was not true agama but only adat. The Balinese responded by stressing their Indian affiliation so as to benefit from the prestige of Hinduism, while making a supreme deity out of Sang Hyang Widhi, with a view to presenting their system of beliefs in a monotheistic light. This initiative proved successful since Balinese religion, from then on entitled Agama Hindu Dharma, was officially acknowledged in 1962 by the Department of Religion. The main instrument of this achievement has been the Parisada Hindu Dharma, an organization of national importance, founded in Bali in 1959, which is subsidized by the government, and which set itself the task of "regulating, cultivating and developing the religious life of the Hindu community according to the teaching of the scriptures" (Parisada Hindu Dharma, Pedoman dasar dan rumah tangga [Denpasar, 1968], p. 4). In 1963, the Parisada founded the Institut Hindu Dharma, an institute devoted to the study and the promotion of Hindu religion in Bali. On these questions, see A. Forge, "Balinese Religion and Indonesian Identity," in Indonesia: Australian Perspectives, ed. J. J. Fox, R. G. Garnant, P. T. McCawley and J. A. C. Mackie (Canberra: Research School of Pacific Studies, The Australian National University, 1980), pp. 221-33; and Geertz, "Internal Conversion' in Contemporary Bali," in The Interpretation of Cultures, pp. 170-89.

52 See, for example, the program of "Barong and Kris Dance" (above, p.55). A similar view is expressed in Bandem and deBoer, Kaja and Kelod, p. 142.
} 
warning already given a while ago by de Zoete and Spies: "To express the fight between the Barong and Rangda in terms of good and evil is to miss the point." 53

\section{Sacred, Ceremonial, and Secular Dances}

Notwithstanding the conceptual problems raised by this attempt at separating the sacred from the profance, the seminar resulted in a classification distinguishing three categories of dances: ${ }^{54}$

(1) The wali dances ("sacred, religious dances"), which are performed in the inner courtyard of a temple (jeroan) or any other premises where a ceremony is being held, and which are an integral part of the ceremonial proceedings (pelaksana upacara). These are generally devoid of narrative elements, such as in the Pendet, the Rejang, the Baris Gede, and the Sanghyang. ${ }^{55}$

(2) The bebali dances ("ceremonial dances"), which are performed in the middle courtyard of a temple (jaba tengah) or elsewhere, and which are only an accompaniment to the ceremony (pengiring upacara). These include narrative elements, such as in the Wayang, the Topeng, the Gambuh, and other genres which derive from these. 56

(3) The balih-balihan dances ("secular dances"), which are performed in the outer courtyard of a temple (jabaan) or anywhere else, as entertainment (hiburan), independently of any ceremonial context, and which do not belong to the wali or bebali categories.

A cursory reading of the definitions warranting this classification is sufficient to realize that the term balih-balihan does not have any intrinsic content, as it was defined in a residual manner from the sphere previously circumscribed by the wali and bebali categories. Despite this, its meaning is reasonably clear, since being composed from the root -balih it can be translated as "spectacle" (literally "what is being watched"). On the other hand, the distinction between the respective semantic fields of wali and bebali proves more difficult to delineate. ${ }^{57}$ These two terms have in fact as a common

\footnotetext{
${ }^{53}$ De Zoete and Spies, Dance and Drama in Bali, p. 97. Thus, by an irony of fate, the Balinese happen to repeat the mistake which foreign analysts have been accused of committing, that is to say of projecting an ethical interpretation inspired by the Judeo-Christian conception of personal choice and individual responsibility, whereas in fact the forces which operate in Balinese theater express the repercussions of cosmic principles within the human universe. Balinese dancers-at least those among those who are literary minded-refer to these principles with the term dharma (its opposite being a-dharma), which should be understood rather as the suitability of a code of behavior within the social order and its cosmological paragon. For a similar trend in Javanese wayang, see Benedict Anderson, Mythology and the Tolerance of the Javanese (Ithaca: Cornell Modern Indonesia Project Monograph, 1965).

${ }^{54}$ See "Keputusan Seminar Seni Sacral dan Seni Provan Bidang Tari," p. 2 in Seminar Seni Sacral dan Provan Bidang Tari.

55 Rejang and Pendet are both temple dances for women, performed by members of the congregation. The former is in itself an offering, while in the latter the dancers present various offerings to the deities momentarily resting on their shrines during a temple festival. Baris Gede, also called Baris Upacara ("ceremonial Baris"), is generally described as a "warrior dance," in which between four and sixty-four men take part, carrying various attributes.

${ }^{56}$ Wayang is a generic term, referring either to the shadow-puppet theater (wayang kulit), or else to dramatic dance genres in which episodes from the Ramayana (wayang wong) or from the Mahabharata (parwa) are enacted. Topeng is a masked dance-drama based on genealogical chronicles (babad) of the Balinese ruling families. Gambuh is the oldest genre of court theater, presenting episodes from the East Javanese Panji stories, known in Bali as the Malat.

${ }^{57}$ For a recent reassessment of the issue by one of the participants of the 1971 seminar, see G. B. N. Pandji,
} 
etymology the Sanskrit root bali-the very name of this island-which signifies "offering." 58 The official Balinese-Indonesian dictionary however differentiates them by rendering bebali as "offering" (sesajen) and wali as "ceremony" (upacara). 59

Now, if one turns to the dancers themselves, as well as to the village literati, one realizes that the distinction between wali and bebali, so neatly drawn by those urbanized intellectuals in charge of regulating the performance of dances for the tourists, does not really function. 60 The Balinese dancers and literati interviewed on this issue agreed by and large to characterize the wali dances as offerings to the gods presented within the framework of a religious ceremony (ngaturang wali). As for the bebali dances, however, my informants were generally at a loss for a reply, considering them either as being "almost wali" (wewalen) or readily confessing that they did not understand the meaning of this term at all, which seemed hardly to have been in use prior to the seminar.

This conceptual difficulty was further aggravated by the fact that the categories composing the 1971 classification were conceived in terms of contents, in the sense that specific dances were attributed to each one of them, whereas precisely which dance is requested for a given ceremony varies according to local traditions. Thus, not surprisingly, Balinese dancers would often disagree when asked whether a particular dance is a wali or a bebali. In an attempt to address the problem, the same Head of the Balinese Office of the Department of Religion who had played a crucial role in the seminar revised the initial nomenclature in 1978. Stressing the function of each category instead of its contents, he proposed that bebali dances be considered as wali when they contribute to the completion of a ceremony (menunjang pelaksanaan upacara), and as balihbalihan when they are presented as mere entertainment (tontonan biasa). 61

This revision amounted, in fact, to eliminating the category bebali altogether, with the result that the so-called "ceremonial dances," which traditionally combined a ritual purpose with a dramatic content, tended thereafter to be considered univocally, either as a ritual (wali) or as an entertainment (balih-balihan), according to the context-religious or secular-of their performance.

What happened between the sudden appearance of the category bebali-or to be more precise, its accentuation-in 1971, and its discrete disappearance in 1978? According to the participants of the seminar, all "traditional dances" (tarian kuno)-namely the ones predating the arrival of Kebyar and the coming of tourists-were performed in the context of a religious ceremony, and were therefore grouped under the appelation

"Seni Wali di Bali dan Perkembangannya," in Laporan Pertemuan Ilmiah Kebudayaan Bali (Denpasar: Proyek Penelitian dan Pengkajian Kebudayaan Bali, 1985), pp. 469-82.

58P. J. Zoetmulder, Old Javanese-English Dictionary (The Hague: Nijhoff, 1982), p. 197.

${ }^{59}$ Warna, Kamus Bali-Indonesia, pp. 68,640 . The difficulty of making a clear and precise distinction between the categories of wali and bebali is also found in a very similar way within the field of traditional textiles, where each of these two terms refers to fabrics whose design reserves exclusive usage within a religious context.

${ }^{60}$ Here I refer to the distinction made by Robert Redfield between the literati and the intelligentsia. Whereas the former are still enclosed-up to a certain point-within their traditional worldview, which they take for granted, the latter bestride two worlds, the society out of which they arose and the world at large, which is increasingly impinging upon it. To some extent, the mediating role traditionally performed by the panasar is now taken over by the Balinese intelligentsia, who mediate between the villages, Denpasar, and Jakarta on the one hand, and between Bali and the outside world on the other.

${ }^{61}$ See G. A. G. Putra, Hubungan seni tari Bali dengan Agama Hindu (Denpasar: Institut Hindu Dharma, 1978), p. 1. 
wali. The perceived risk of profanation entailed by touristic commercialization was to lead the intelligentsia to proceed to a conceptual discrimination within this as yet undifferentiated whole, by deciding which dances could be separated from their ceremonial context in order to be performed for the tourists. Hence the advent of a novel category, that of the bebali dances. But then, the very fact that these dances perform a "dual function" (dwi fungsi)-a ritual function (fungsi rituil), and an entertaining function (fungsi hiburan)-rendered it necessary to discriminate further between their performances, thus bringing about the eventual splitting of the bebali category. 62

\section{Ritual or Entertainment?}

In 1973, a decree of the Governor of Bali ratified the conclusions of the seminar by prohibiting the commercialization of "sacred dances" - namely the ones considered to belong to the wali category. Thus, while the tourists were permitted to watch wali dances whenever they were performed in the context of a ceremony, these dances should not have been deliberately staged as a tourist attraction. With regard to the bebali dances, the decree remained ambiguous, because though not expressly forbidding their presentation to the tourists, it nevertheless reserved those dances to their ceremonial context. ${ }^{63}$ Such imprecision is indicative of the conceptual problems raised by the 1971 classification, confirmed by the avowed incapacity of the Balinese authorities to enforce the new regulation.

How does this decree apply to the various genres of tourist performances previously described? The "Legong Dance" and the "Ramayana Ballet" clearly belong to the balihbalihan category, and consequently their use as tourist attractions is authorized. On the other hand, the Pendet and the Sanghyang come under the wali category, which prohibits their performance to the tourists. But then, what of the tourist spectacles making use of Rangda and Barong, which are not mentioned in the classification? And what about those derived from the Sanghyang, whose commercialization is officially forbidden?

Even though the Kecak was originally a part of a ritual, it is nowadays generally regarded by the Balinese as an entertainment destined for tourist audiences. This is not the case with the so-called "Angel Dance" and "Fire Dance," which are seen as an imitation of the Sanghyang Dedari and of the Sanghyang Jaran. As such, these spectacles are expressly prohibited, even if they continue to be regularly advertised by the Bali Tourism Promotion Board. And then, inasmuch as Rangda and Barong were not specifically mentioned in the classification, the performances of "Barong and Kris Dance" appear to have an ambiguous status for the Balinese, whose opinions on the matter are rather irresolute.

62 The fate of the wali category reminds one of what happened to the adat category through the process of religious rationalization previously mentioned. One could represent this twofold process by means of the following diagrams:

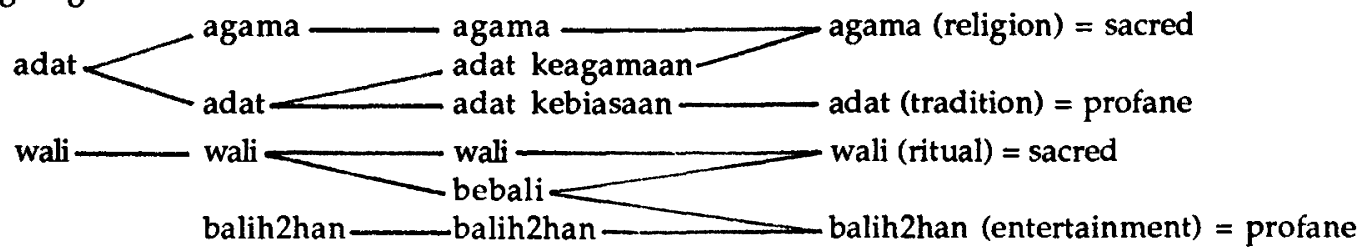

${ }^{63}$ S. K. Gubernur Kepala Daerah Propinsi Bali No.2/Kesra. II/d/26/1973 tentang Pelarangan Pergelaran Taritarian Wali/Tarian Upacara untuk Turis dan secara umum. 
In order to throw some light on the debate, the Head of the Department of Religion reconsidered the issue in 1980 . This time, he proposed as criterion for defining the wali dances the fact that the dancers as well as their equipment-such as head-dresses, masks, and krisses-have to undergo a consecration ritual. ${ }^{64}$ As a consequence, tourist spectacles inspired by wali dances could be performed as long as they did not resort to consecrated dancers and accessories.

Once an agreement had been reached about the necessity of reserving the use of consecrated accessories for the execution of wali dances, it was not surprising to learn that the officials asked about this question all readily expressed the belief that the headdresses, masks, and krisses used in tourist performances had not been consecrated. What is more suprising is to find the same conviction shared by a number of foreign observers, who assert that the tourist performances of "Barong and Kris Dance" do not utilize consecrated masks of Rangda and Barong. 65

The observation of the "Barong and Kris Dance" at Batubulan, as well as of the spectacles of "Monkey Dance," "Angel Dance," and "Fire Dance" at Bona, contradicted this conviction, demonstrating again the difficulty encountered by the Balinese in distinguishing between the ritual and spectacular dimensions of a performance, even as commercial as its purpose might appear. Thus it became clear that attractions expressly designed for a tourist audience usually employed the same ritual procedures as the ceremonies which they imitate, namely the use of consecrated implements and the presentation of offerings before and after the performance. These offerings (banten) are presented to ensure help and protection from invisible (niskala) forces, as well as to prevent the disturbances brought about by the buta kala which occupy the premises.

Now, why are Balinese dancers so reluctant to do without consecrated accessories, even when performing for a tourist audience? When interviewing dancers of the "Barong and Kris Dance" at Batubulan, I was repeatedly given as a reason the fact that unless they had undergone a consecration ritual, the masks of Rangda and Barong were but "dead" (mati) objects. Consequently, the use of consecrated masks in a performance was a way to make it come "alive" (idup), and thus to ensure its success with the audience-and this, even when the audience was made up of non-Balinese. But then, the consecration of a mask renders it sakti, meaning that it becomes a vehicle for a supernatural power, which can make its presence felt by taking possession of the dancer (karauhan). Thus, through the use of consecrated masks of Rangda and Barong, a tourist performance of "Barong and Kris Dance" may become magically efficient, and therefore dangerous. Hence, ritual precautions are required, such as the use of so-called

\footnotetext{
${ }^{64}$ See G. A. G. Putra, Cudamani. Tari Wali (Denpasar, 1980), p. 3. Besides purifying themselves anew before each performance, the dancers of wali dances should have undertaken a ritual purification called mawinten. Accessories such as head-dresses (gelungan), masks (tapel), and krisses (keris), are consecrated after having been made. Furthermore, the masks of Rangda and Barong are endowed with "magic power" (sakti) by means of ritual procedures, which can be succinctly described as follows. Before it could be worked on, the selected piece of wood should be ritually "killed" (pralina). Once the mask is made, it is purified (prayascita) in order to obliterate any trace of pollution (leteh) due to its manipulation. It is then "animated" (utpeti) by a ritual specialist during a ceremony (mapasupati) aimed at enabling the mask to be invested with a supernatural force. In order to test its efficiency, a magic rite has yet to be administered (ngrehang), whose success will confer upon the mask the property of sakti, referring to the power with which it is henceforth endowed.

${ }^{65} \mathrm{See}$, for example, Bandem and deBoer, Kaja and Kelod, p. 148; Eiseman, Bali. Sekala and Niskala, p. 118; Emigh, "Dealing with the Demonic," p. 38; Rickner, Theatre as Ritual, p. 27; A. E. Sanger, "New Patrons of Old Music: The Survival and Revival of the Performing Arts in Bali," Widya Pustaka 5/1 and 2 (1987): 153.
} 
"redeeming offerings" (banten panebusan), as well as special purification rituals aimed at preventing possible risks of "pollution" (leteh), or even of "curse" (pastu).

If this is indeed the case, it becomes understandable that, while acknowledging that the "trance" episodes were simulated, the dancers readily admitted that the occurrences of real possession were not infrequent, and that accidents occasionally occurred during the ngurek episodes. Moreover, both at Batubulan and at Bona, the local people saw these tourist spectacles as still having religious significance, willingly mentioning the magical or mystical benefits bestowed on their village as a result of their performance, as though they did not differentiate between a commercial show and a rite of exorcism. This is all the more striking in the case of Bona where-at least according to my informants, who unanimously agreed on that point-the ceremonies of ritual Sanghyang had ceased by the end of the 1930s, following the eradication of the recurring epidemics which they sought to keep under control. ${ }^{66}$

Therefore, it becomes difficult to agree with those who assert that the aesthetic effects of a performance of Rangda and Barong are separable from its ritual effects. ${ }^{67}$ Indeed, such a distinction could only appear to be so well defined from the point of view of a foreign observer, but not of a Balinese dancer, for whom the wearing of a consecrated mask is indispensable not only to the ritual fulfillment of the performance, but equally so for its success as a spectacle. The only Balinese who might make a distinction between ritual and entertainment are those officials and other intellectuals charged with the task of conceptualizing a response to the "challenge of tourism." Such a distinction is not, however, adopted by the dancers, who are more directly concerned with the impression made by their performance on the audience.

In this sense, and contrary to religious officials, Balinese dancers do not consider disassociating the sacred from the profane and do not seem to have any difficulty in dealing with ambiguity. In short, while the regional authorities endeavor to "disenchant" parts of the world, the dancers continue to move in a totally "enchanted" world. So much so that, even though Balinese officials persist in asserting sententiously, like that villager quoted by Annette Sanger: "In the temple we ask for a blessing, and at a hotel we ask for money";68 one may rightfully ask whether the day is really that far away when Balinese dancers will think, in the manner of that cartoon published in Playboy: "It's a ritual dance to ask the gods for a lot of tourists." 69

\section{From Discrimination to Confusion}

This conclusion leads us to examine the implications of the measures adopted by the

${ }^{66}$ The villagers of Bona do not seem to be the only ones to mistake the tourist spectacle for the Balinese ritual of Sanghyang, judging by the photos of the so-called "Sanghyang Dedari" illustrating the book of Bandem and deBoer, which have all been taken in Bona (Bandem and deBoer, Kaja and Kelod). If it is true that the ceremonies of Sanghyang have indeed vanished from this village, what could these photos of "Sanghyang in trance" represent other than an attraction intended for the tourists? The same comment applies to the photos of the so-called "Calonarang" in the same book-as well as in several other books-which were actually taken during a performance of the "Barong and Kris Dance" at Denjalan, in Batubulan. As already mentioned, these performances do not deal with the theme of Calonarang but with that of Kunti Sraya.

${ }^{67}$ See, for example, Rickner, Theatre as Ritual, p. 302.

${ }^{68}$ A. E. Sanger, "The Role of Music and Dance in the Social and Cultural Life of Two Balinese Villages" (PhD dissertation, University of Belfast, 1986),. p. 296.

${ }^{69}$ Quoted in J. Jafari, Review of J. D. Sweet, "Dances of Tewa Pueblo Indians," Annals of Tourism Research 13/2 (1986): 310 . 
regional authorities in order to prevent the undesired consequences of the touristic commercialization of Balinese dances. As long as tourist performances were restricted to those dances already separated from their dramatic content and their ritual significance, no one found anything to complain about-except for some old-fashioned literati, supported by a handful of foreign connoisseurs, worried by the growing impoverishment and routinization of dance and drama in Bali. After all, it was only those spectacles already considered mere entertainment by the Balinese which were being adapted to the taste of a foreign audience. However, when the tourist trade started to interfere a little too openly with dances reserved until then for ritual purposes, the cultural and religious authorities of the island were troubled and decided that it was time for them to intervene. In the first case, in effect, the tourist performances were part of a contemporary Balinese tendency to dissociate entertainment from ritual, whereas in the second case they had openly turned ancient Balinese rituals into new forms of tourist entertainment. The reaction of the authorities was consequently to strive to separate the dances which had to remain "bound" (terikat) to their ceremonial context from those which could be "detached" (terlepas) from this context without excessive remorse.

This attempt at protection tended at first to widen the gap between the ritual and spectacular aspects of dance. Thus the official distinction between the wali and the balihbalihan dances has resulted in rendering residual the intermediary category of bebali dances, whose ritual and dramatic aspects were inseparable until then. But one also notices that the performance of bebali dances has tended to become standardized, with the same dances now being presented to Balinese audiences within the framework of religious ceremonies, as well as expressly offered as an attraction to the tourists. More precisely, the recent evolution of certain dramatic genres originally labeled bebali-such as the Gambuh for example-reveals that the balih-balihan version initially designed for foreign spectators and therefore simplified, shortened, and standardized on the pattern of the Sendratari, is now being performed in a precisely identical manner in ceremonial contexts as a wali. Hence the risk of confusion between wali and balihbalihan dances, which no longer have any distinguishing features outside the circumstances surrounding their performance.

Thus it is that, while striving to keep ritual separate from entertainment, in order to prevent the profanation of the "sacred dances" by indiscriminate exploitation for commercial ends, the measures adopted by the regional authorities might in fact have contributed to the confusion between performances reserved for the Balinese and those destined for the tourists.

\section{The Bali Arts Festival}

It seems to me that it is precisely in this confusion that one has to look for an explanation of the volte-face of opinion among the Balinese authorities regarding tourism.

Nowadays, the classification resulting from the seminar of 1971 continues to be piously referred to, but it appears clear that the tone has changed and that the former conviction has given way to the force of habit. Moreover tourism, which was formerly accused of subverting the most fundamental Balinese cultural values and which was held responsible for degrading traditional dances to the rank of "floor-shows," is now said to be the moving force behind the "cultural renaissance" which is supposed to be flourishing in recent day Bali. Thus one can read, for example, in the booklet presenting the Art Center of Denpasar to the tourists:

The truth is that Bali is undergoing a cultural renaissance with bigger and brighter 
temple festivals, revived art forms and more orchestras than ever before. ${ }^{70}$

The success of the annual "Bali Arts Festival" (Pesta Kesenian Bali), which was launched in 1979, is generally expounded as evidence of this alleged "renaissance," of which the Balinese officials proudly talk whenever a foreign journalist ventures to worry about the risks the massive influx of tourists presents to their traditions. The initiative came from the new Governor-a Balinese academic and former Director General of Culture in Jakarta-who wanted to organize a series of annual dance and art festivals in Denpasar, to foster Balinese artistic creativity while at the same time stimulating tourist promotion of the island.

I decided to pay particular attention to the Arts Festival because this event, by its very recurrence, appears to reveal what has become of Bali and its culture today. Indeed, here we are dealing with a monumental cultural performance at the level of this island as a whole, where Balinese culture-in its official version-is exhibited in a concentrated and magnified fashion. And above all, contrary to what one could have expected, this performance is not so much intended for the foreign tourists as for the Indonesians, and even more so for the Balinese themselves, if one considers that they make up the main part of the audience for the festival.

Now, what is to be seen there? Mostly dance performances, among which one can distinguish several categories. First, forms of court theater rapidly going out of fashion, which the festival is expected to preserve and revitalize. Then, dramatic genres which are still occasionally performed in the villages but are suffering from a decline of popularity. And finally, large scale Sendratari, generally based on the Ramayana or else on the Mahabharata. This last genre has always undisputably been the chief attraction of the festival, the performance provided with the largest budget as well as being the most painstakingly prepared and the most elaborately staged. Above all, this is the attraction that draws by far the largest audiences, Balinese and tourists alike.

One thus notices that the festival emphasizes precisely those spectacles initially designed to appeal to the taste of foreign audiences, and therefore departing to a considerable extent from the traditional standards of Balinese theater. Even more so, it is precisely one of the most famous tourist performances, the Sendratari Ramayana-alias the "Ramayana Ballet"-which is presented as an "authentic Balinese tradition" (tradisi Bali yang asli), whose continuous success is meant to testify to the artistic vitality of the island. Up to the point that the chairman of the festival committee declared in 1980 that: "the primary goal of the festival is the development of traditional Balinese art in the form of the Sendratari Ramayana."71 The offical recognition of the Sendratari as the Balinese dramatic genre par excellence appears to be taken for granted today, judging by the paper presented by the director of the Academy of Dance to a "Seminar on the contribution of Balinese cultural values to the development of the national culture" (Seminar Sumbangan Nilai Budaya Bali dalam Pembangunan Kebudayaan Nasional), organized in 1984 in Denpasar: the author advocates extensively popularizing the Sendratari throughout the villages, since it is, according to him, the dramatic genre

\footnotetext{
${ }^{70}$ M. Wijaya, Bali's Art Centre, Werdi Budaya, and the Annual Festival of the Arts (Denpasar: Bali Government Tourist Office, 1981), p. 1.

71 "Pembinaan seni tradisional Bali sebagai prioritas utama dalam wujudnya dengan menampilkan pergalaran Sendratari Ramayana" (statement broadcast on radio and television June 11, 1980; typewritten text personally conveyed to me by the author).
} 
which is the most qualified to insure the conservation of Balinese cultural values. ${ }^{72}$

Thus one notices that after barely two decades of existence, the Sendratari, which was after all originally created for non-indigenous audiences, could actually succeed in forcing recognition to such an extent that it is now presented as the very exemplar of Balinese cultural values. Such being the case, however, one should no longer be surprised to read in an Indonesian study dealing with the expected consequences of the commercialization of Balinese culture by tourism, that: "the integrity of the Sendratari Ramayana is lost as a result of its being performed for a tourist audience."73

\section{From "Cultural Tourism" to "Touristic Culture"?}

Taking into account the fact that tourist performances are now acknowledged as Balinese traditions, one might be tempted to conclude that, between the seminar of 1971 and the festival of 1979, a reversal had taken place in the attitude of the Balinese authorities, who renounced their concern for cultural protection and completely gave in to the demands for tourist promotion. In short, from now on, it seems to be not so much a matter of restricting the encroachment of tourism on Balinese culture, as of reaping the benefits from all the assets liable to ensure the success of Bali on the international tourist market. Under these circumstances, the question as to whether or not certain dances are merely tourist attractions or traditional cultural performances loses its relevance. And even more so, it appears that the confusion between one and the other could be a requisite condition, allowing the Balinese authorities to declare that the presence of tourists exerts a stimulating effect on artistic creativity, and thus to legitimize the policy of turning Bali's cultural performances into a tourist attraction.

Yet, it seems difficult to assert that the initial concern for cultural protection has been forsaken under the pressure of tourist promotion, if only because the audience of the Arts Festival is mainly made up of the Balinese themselves. If such were indeed the case, it would not make much sense for the organizers of the festival to have come to consider the tourist attractions presented to the Balinese audience as a protective measure against the penetration of foreign cultural influences spread by the tourists.

In my opinion, the confusion, which one observes in today's Bali, between what belongs to "culture" and what pertains to "tourism," is the direct and logical outcome of the policy of "cultural tourism." Faced with what they perceived as a dilemma-how to use culture to promote tourism without debasing culture in the process-the Balinese authorities decided to merge their cultural and tourist policies, and this decision led them to assimilate their respective objectives. ${ }^{74}$ This, in turn, implied a disjunction in

72 "Sendratari Mahabharata dan Ramayana yang kini sedang dicintai oleh masyarakat sudah sepatutnya ditata dalam kelompok yang lebih sederhana ... sehingga dengan mudah dapat diteruskan ke dalam masyarakat untuk memelihara dan melestarikan nilai budaya Bali" (M. Bandem, "Transformasi Kesenian dalam Melestarikan Nilai Budaya Bali," in Sumbangan Nilai Budaya Bali dalam Pembangunan Kebudayaan Nasional, ed. G. Ng. Bagus [Denpasar: Proyek Penelitian dan Pengkajian Kebudayaan Bali, 1986], p. 55).

73 “Untuk kepentingan wisatawan Sendratari Ramayana tidak lagi disajikan secara untuh" (O. A. Yoeti, Komersialisasi Seni Budaya dalam Pariwisata [Bandung: Angkasa, 1985], p. 14).

${ }^{74}$ Witness the signature in 1979 of an agreement between the General Directorate of Culture (Ditjen Kebudayaan) and the General Directorate of Tourism (Ditjen Pariwisata), which resulted in the creation of a "Commission of Cooperation for the Development of Cultural Tourism" (Komisi Kerjasama Pembinaan dan Pengembangan Wisata Budaya). The objectives of this commission have been defined as follows: "to increase and extend the use of cultural objects for the development of tourism, and to use the proceeds of tourism development for the building and the development of culture" ("meningkatkan dan memperluas pemanfaatan obyek-obyek kebudayaan bagi pengembangan kepariwisataan dan hasil-hasil pengembangan 
the Balinese view of their culture, simultaneously perceived as a "cultural heritage" (warisan kebudayaan), which they should look after, and as "tourist capital" (modal pariwisata), which they could exploit. Thus, insofar as it assures the touristic appeal of the island, Balinese culture becomes at once a "value to defend" (nilai yang harus ditahankan) and a "value to market" (nilai yang harus dipasarkan).

In other words, their culture has become for the Balinese, on the one hand what characterizes them as a specific society, and on the other hand what provides their tourist product with its distinguishing features-both an identity marker (ciri khas) and a trademark. Accordingly, one has grounds for inferring that the doctrine of "cultural tourism" (pariwisata budaya) is turning Balinese culture into what could be termed a "touristic culture" (budaya pariwisata) - that is, a culture characterized, according to the Balinese themselves, by a confusion between the values of culture and those of tourism-precisely what this doctrine was initially aimed at avoiding at all costs.

It should be clear by now that the oft-repeated question "Can Balinese culture survive the impact of tourism?" is not a relevant one. Tourism is not an external force striking Bali from outside, like a missile hitting a target, but it is a process transforming Balinese society from inside-today, tourism has become an integral part of Bali's culture.

Therefore, the question one should ask concerns not so much the "impact" of international tourism upon Balinese culture, but rather the significance of the term "Balinese culture" (kebudayaan Bali), which inspires as much concern on the part of the regional authorities, as it fills foreign visitors with admiration. It seems to me that this is in fact the product of dialogic construction between the Balinese and their various interlocutors, in a context defined by the growing integration of Bali within the overlapping networks of the international tourist industry and of the Indonesian stateincluding the tourists, foreign as well as domestic, but also the artists and anthropologists who contributed to the creation of the touristic image of Bali, not to forget the Dutch officials who incessantly endeavored to shape Balinese society according to their idea of how it should be, and their Indonesian successors who are following their lead.

This "Balinese" culture, which the Arts Festival celebrates each year with increasing splendor, nowadays defines the identity of the Balinese (identitas Bali), not only with respect to the outside world but even more importantly with respect to the Balinese themselves. This process has been aptly summarized by Adrian Vickers, in a discussion of the evolution of the Gambuh:

This "culture," expressed in art and religion, is what is promoted in tourist literature, what tourists come to see, and what is eventually accepted by the Balinese themselves as a definition of what is important in their own society. ${ }^{75}$

Hence, comforted by the approbation of both tourists and Indonesians, the Balinese are becoming self-conscious spectators of their own culture-taking the growing touristification cum Indonesianization of their culture as the very proof of its "renaissance."

kepariwisataan bagi pembinaan dan pengembangan kebudayaan"). See Ditjen Kebudayaan, Naskah Kerjasama Ditjen Kebudayaan dan Ditjen Pariwisata (Jakarta: Departemen P \& K, 1979), p. 6.

75 A. H. Vickers, "The Desiring Prince: A Study of the Kidung Malat as Text" (PhD dissertation, University of Sydney, 1986), p. 302. 